OPEN ACCESS

Edited by:

Jean van den Elsen,

University of Bath, United Kingdom

Reviewed by:

John Bernet Johnson,

Rajiv Gandhi Centre for Biotechnology,

India

Péter Gál,

Hungarian Academy of Sciences

(MTA), Hungary

*Correspondence:

Anna M. Blom

anna.blom@med.lu.se

Specialty section:

This article was submitted to

Molecular Innate Immunity,

a section of the journal

Frontiers in Immunology

Received: 17 June 2021

Accepted: 12 August 2021 Published: 01 September 2021

Citation:

Bettoni S, Maziarz K, Stone MRL,

Blaskovich MAT, Potempa J,

Bazzo ML, Unemo M, Ram S and Blom AM (2021) Serum Complement

Activation by C4BP-IgM Fusion Protein Can Restore Susceptibility to Antibiotics in Neisseria gonorrhoeae.

Front. Immunol. 12:726801.

doi: 10.3389/fimmu.2021.726801

\section{Serum Complement Activation by C4BP-IgM Fusion Protein Can Restore Susceptibility to Antibiotics in Neisseria gonorrhoeae}

\author{
Serena Bettoni ${ }^{1}$, Karolina Maziarz ${ }^{1}$, M Rhia L Stone ${ }^{2}$, Mark A T Blaskovich ${ }^{2}$, \\ Jan Potempa ${ }^{3,4}$, Maria Luiza Bazzo ${ }^{5}$, Magnus Unemo ${ }^{6}$, Sanjay Ram ${ }^{7}$ and Anna M. Blom ${ }^{1 *}$ \\ ${ }^{1}$ Department of Translational Medicine, Lund University, Malmö, Sweden, ${ }^{2}$ Centre for Superbug Solutions, Institute for \\ Molecular Bioscience, The University of Queensland, Brisbane, QLD, Australia, ${ }^{3}$ Faculty of Biochemistry, Biophysics and \\ Biotechnology, Jagiellonian University, Kraków, Poland, ${ }^{4}$ Department of Oral Immunity and Infectious Diseases, University of \\ Louisville School of Dentistry, Louisville, KY, United States, ${ }^{5}$ Molecular Biology, Microbiology and Serology Laboratory, \\ Federal University of Santa Catarina, Florianópolis, Brazil, ${ }^{6}$ World Health Organization (WHO) Collaborating Centre for \\ Gonorrhoea and other STIs, Department of Laboratory Medicine, Örebro University, Örebro, Sweden, ${ }^{7}$ Department of \\ Medicine, Division of Infectious Diseases, University of Massachusetts Medical School, Worcester, MA, United States
}

Neisseria gonorrhoeae is the etiological agent of gonorrhea, the second most common bacterial sexually transmitted infection worldwide. Reproductive sequelae of gonorrhea include infertility, ectopic pregnancy and chronic pelvic pain. Most antibiotics currently in clinical use have been rendered ineffective due to the rapid spread of antimicrobial resistance among gonococci. The developmental pipeline of new antibiotics is sparse and novel therapeutic approaches are urgently needed. Previously, we utilized the ability of $\mathrm{N}$. gonorrhoeae to bind the complement inhibitor $\mathrm{C} 4 \mathrm{~b}$-binding protein (C4BP) to evade killing by human complement to design a chimeric protein that linked the two $\mathrm{N}$-terminal gonococcal binding domains of $\mathrm{C} 4 \mathrm{BP}$ with the $\mathrm{Fc}$ domain of $\mathrm{IgM}$. The resulting molecule, C4BP-IgM, enhanced complement-mediated killing of gonococci. Here we show that C4BP-IgM induced membrane perturbation through complement deposition and membrane attack complex pore insertion facilitates the access of antibiotics to their intracellular targets. Consequently, bacteria become more susceptible to killing by antibiotics. Remarkably, C4BP-IgM restored susceptibility to azithromycin of two azithromycin-resistant clinical gonococcal strains because of overexpression of the MtrC-MtrD-MtrE efflux pump. Our data show that complement activation can potentiate activity of antibiotics and suggest a role for C4BP-IgM as an adjuvant for antibiotic treatment of drug-resistant gonorrhea.

Keywords: complement, antibiotic resisitance, Neisseria gonorrhoeae, C4b binding protein, membrane attack complex (MAC) 


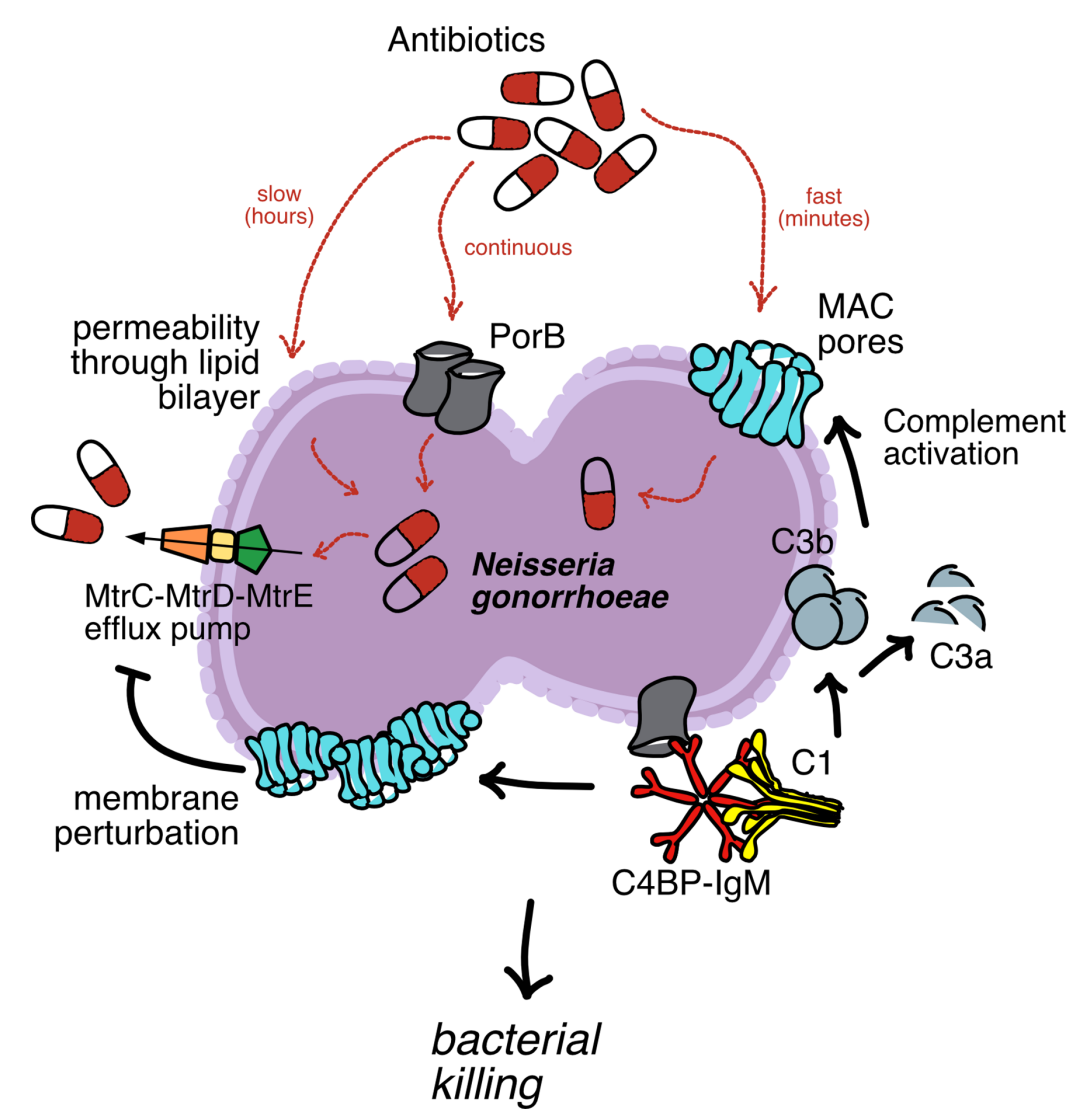

GRAPHICAL ABSTRACT | Antibiotics reach their intracellular targets via passive permeability across the lipid bilayer or through the membrane porin channels used by bacteria to exchange material with the environment. As a resistance mechanism, bacterial cells actively eliminate antibiotics from inside the cells using efflux pumps located on their membranes. The fusion protein C4BP-IgM binds to bacteria and induces rapid complement activation via classical pathway (C1 binding), which rapidly promotes C3b deposition, C3a release and formation of membrane attack complex (MAC) pores on the outer membrane. In turn, MAC pores perturbate the integrity of the membrane that inactivate efflux pumps. Further, MAC pores provide additional channels on bacteria membrane for antibiotic uptake in cell. Together, these events enhance bacteria killing.

\section{INTRODUCTION}

Neisseria gonorrhoeae is an obligate human pathogen that infects mucosal surfaces and causes the sexually transmitted infection gonorrhea (1). In 2016 the World Health Organization (WHO) estimated the global incidence rate of gonorrhea in persons aged between 15 and 49 years to be 86.9 million (2). If untreated, gonorrhea can cause serious complications, including pelvic inflammatory disease, infertility, and ectopic pregnancy in women and blindness in new-born babies (3-5). Gonorrhea also augments the risk of HIV transmission (6).

An effective anti-gonococcal vaccine remains elusive; control measures mainly include prevention, rapid diagnosis and antibiotic

Abbreviations: AF, Alexa Fluor; GC, gonococcal; BSA, bovine serum albumin; CABP, C4-binding protein; CCCP, efflux pump inhibitor carbonyl cyanide 3chlorophenylhydrazone; CFU, colony forming unit; DAPI, diamidino-2phenylindole; gMFI, geometric mean fluorescence intensity; GVB, gelatin veronal buffer; Ig, immunoglobulin; HBSS, Hanks Balanced Salt Solution; MAC, membrane attack complex; NHS, normal human serum; OD, optical density; OmCI, Ornithodoros moubata complement inhibitor; AMR, antimicrobial resistance; Cp40, compstatin. treatment. Gonococci have become resistant to almost all currently available antibiotics (7). The extended-spectrum third-generation cephalosporin ceftriaxone, often given in combination therapy with azithromycin, is the last alternative for first-line monotherapy of gonorrhea and recommended by the WHO and other international or national public health organizations (8-12). Resistance and/or decreased susceptibility to ceftriaxone has however been reported worldwide and occasional gonorrhea treatment failures with recommended dual therapy (ceftriaxone plus azithromycin) and especially ceftriaxone monotherapy was verified internationally $(13,14)$. Drug-resistant $N$. gonorrhoeae is listed as an 'urgent threat' in the 2019 USA CDC report (15), while the WHO listed cephalosporin-resistant, fluoroquinolone-resistant $N$. gonorrhoeae as a high priority in 2017 (16). The spread of azithromycin-resistant $N$. gonorrhoeae strains resulted in the US CDC no longer recommending azithromycin against gonorrhea (11).

N. gonorrhoeae has an extraordinary propensity to develop antimicrobial resistance (AMR) through several mechanisms, including inactivation by enzymatic cleavage, alterations of 
antibiotic targets, and enhanced extrusion or reduced uptake of drugs by efflux/influx pumps (17). The multiple transferable resistance ( $m t r)$ operon in $N$. gonorrhoeae encodes membrane proteins that form an energy-dependent efflux pump system (MtrC-MtrD-MtrE), which removes drugs and hydrophobic agents from inside the cells into the extracellular space (18). Some gonococcal strains acquire resistance to azithromycin by deletions in the $m t r R$ promoter region (MtrR is a repressor of $m t r C D E)$ or gain-of-function mutations in mosaic $m t r$ efflux pump alleles which result in overproduction/overactivation of efflux pump proteins $(19,20)$. Mtr AMR determinants combined with mutations in genes for the penicillin binding protein 2 (PBP2) and Porin (PorB1b) decrease susceptibility to ceftriaxone (21).

To counteract the increasing spread of AMR N. gonorrhoeae, alternative therapies have been proposed. Utilizing the capability of $N$. gonorrhoeae to recruit the complement inhibitor $\mathrm{C} 4 \mathrm{~b}-$ binding protein $(\mathrm{C} 4 \mathrm{BP})$ to evade complement-dependent killing, we previously created a human fusion protein comprising the gonococcal binding domains of $\mathrm{C} 4 \mathrm{BP}$ and the Fc backbone of IgM (C4BP-IgM) (22). Binding of C4BP-IgM to gonococci activated complement and led to the assembly of the membrane attack complex (MAC), resulting in bacterial death. C4BP-IgM promoted complement-mediated killing of several clinical gonococcal isolates and efficiently eradicated bacteria in the mouse vaginal colonization model (22).

Evidence of cooperation between complement activation and antibiotics in killing bacteria dates back to the 1980s (23-27), but the precise molecular mechanisms underlying this effect have remained elusive. Prior studies showed that activation of human complement promoted the ability of polymyxin to produce lesions in the outer membrane of gram-negative bacteria (28, 29). Other reports suggested that sensitization by serum of bacteria to antibiotics is independent of active complement, because serum inactivated at $56^{\circ} \mathrm{C}$ retained activity. Mechanisms for the cooperative activity posited a role for IgG (30) and an undefined diffusible serum factor (31). A recent study demonstrated that MAC insertion in the outer membrane of gram-negative bacteria sensitized them to nisin and vancomycin, antibiotics that otherwise are active only against gram-positive organisms (32), thereby demonstrating a cooperative effect between complement and antimicrobials. In this study we ask whether C4BP-IgM-mediated complement activation could potentiate killing of $N$. gonorrhoeae by antibiotics and restore susceptibility in drug-resistant isolates.

\section{MATERIALS AND METHODS}

\section{Bacterial Cultures}

FA1090 strain was used as reference laboratory strain for the majority of in vitro experiments (33). FL29 and SA94 gonococcal strains were isolated in Brazil 2015-16 and examined by whole genome sequencing. Both have azithromycin MICs of $4 \mu \mathrm{g} / \mathrm{mL}$, lack of azithromycin resistance-associated $23 \mathrm{~S}$ rRNA gene mutations, and have mosaics in the $m$ trRCDE operon resulting in an overexpression of the MtrC-MtrD-MtrE efflux pump that causes the resistance to azithromycin (21). All N. gonorrhoeae strains/isolates were stored frozen at $-80^{\circ} \mathrm{C}$ in trypticase soy broth containing $20 \%$ glycerol.

\section{Proteins, Antibodies, and Consumables}

Chocolate agar plates were prepared from Gonococcal (GC) agar base (Difco, 228950) (34). GC liquid growth media was prepared as reported (35). CellTrace Calcein Violet (CV, C34858), sytox green (S7020), FM4-64X (F34653), L-homopropargylglycine (HPG), AlexaFluor488 azide (A10266), Click-iT reaction cocktail (C10269), BCA protein assay kit (23225) and Halt Protease and Phosphatase inhibitor (1861281) were obtained from Thermo Fisher Scientific. Hanks Balanced Salt Solution containing $0.15 \mathrm{mM} \mathrm{CaCl}_{2}$ and $1 \mathrm{mM} \mathrm{MgCl}_{2}\left(\mathrm{HBSS}^{++}\right)$was purchased from Gibco (14025092). Azithromycin dihydrate (PZ0007), ceftriaxone sodium (PHR1382), ciprofloxacin (17850), cefixime trihydrate (18588), spectinomycin (S4014), anti-human IgM CF647 antibody (SAB4600436), efflux pump inhibitor carbonyl cyanide 3-chlorophenylhydrazone (CCCP, C2759) and fluorescent mounting medium without 4',6diamidino-2-phenylindole (DAPI; Dako, S3023) or with DAPI (DUO82040) were purchased from Sigma-Aldrich. Ornithodoros moubata complement inhibitor (OmCI) was prepared as described previously (36). C4BP-IgM was constructed by subcloning CCP1-2 domains of $\mathrm{C} 4 \mathrm{BP}$ and the $\mathrm{CH} 2-\mathrm{CH} 4$ constant portion of human IgM into the expression vector pClaire. Recombinant C4BP-IgM was stably expressed in adherent $\mathrm{CHO}$ cells and purified by affinity chromatography using a specific anti-C4BP antibody as described previously (22). Purified C4BP and C4BP-IgM were fluorescent labeled using AlexaFluor-647 (A30009) or AlexaFluor-488 (A10235) labeling kits from Molecular Probes. Cipro-NBD and Roxi-NBD were synthesized as previously described $(37,38)$. Human antimicrobial peptide LL-37 (LLGDFFRKSKEKIGKEFKRIVQR IKDFLRNLVPRTES) was synthesized by using Fmoc solidphase peptide synthesis and purchased from GenScript (Piscataway, NJ, USA).

\section{Human Complement}

Normal Human Serum (NHS) was obtained from whole blood collected from normal healthy adult volunteers (2019/14) as described (22) and stored at $-80^{\circ} \mathrm{C}$ until use. Heat-inactivated serum (HINHS) was prepared by incubation for $30 \mathrm{~min}$ at $56^{\circ} \mathrm{C}$. $\mathrm{C} 3$ and C5 activation were blocked by treating NHS for $30 \mathrm{~min}$ on ice with the C3-targeted complement inhibitor Cp40 $(50 \mu \mathrm{M})$ (39) or with the C5-inhibitor OmCI $(25.3 \mu \mathrm{g} / \mathrm{mL})$, respectively.

\section{Minimum Inhibitory Concentration (MIC) Evaluation}

Gonococci were grown on GC agar plate overnight at $37^{\circ} \mathrm{C}$ in a $5 \%$ $\mathrm{CO}_{2}$-enriched atmosphere, and then subcultured in GC liquid medium from $\mathrm{OD}_{600 \mathrm{~nm}} 0.1$ until $0.3-0.4$ for $4-5$ hours at $37^{\circ} \mathrm{C}$, on a rotary shaker. After incubation, bacterial concentration was adjusted to $\mathrm{OD}_{600 \mathrm{~nm}} 0.1$ in new GC liquid medium supplemented with $10 \%$ NHS and increasing concentrations of antibiotics (spectinomycin, ciprofloxacin and azithromycin). 
Bacterial growth was monitored by $\mathrm{OD}_{600 \mathrm{~nm}}$ measure every 10 min by Cytation 5 reader (BioTek Instruments, Inc).

\section{Serum Bactericidal Assay}

Bactericidal assays with NHS in the presence of C4BP-IgM fusion protein were performed as described previously (22). Bacteria were cultured on GC agar plate overnight and subcultured on fresh plates for at least 5 hours at $37^{\circ} \mathrm{C}$ in a $5 \%$ $\mathrm{CO}_{2}$-enriched atmosphere. Two $\times 10^{5} \mathrm{CFU}$ of harvested $\mathrm{N}$. gonorrhoeae diluted in $\mathrm{GVB}^{++}(5 \mathrm{mM}$ veronal buffer [pH 7.3], $140 \mathrm{mM} \mathrm{NaCl}, 0.1 \%$ gelatin, $1 \mathrm{mM} \mathrm{MgCl}_{2}$, and $5 \mathrm{mM} \mathrm{CaCl}_{2}$ ) were incubated with NHS in the presence or the absence of antibiotics and C4BP-IgM fusion protein in a final volume of 100 $\mu \mathrm{L}$. Concentrations of each component are indicated for each graph. Aliquots of $25 \mu \mathrm{L}$ of the reaction mixtures were serially diluted in PBS and $10 \mu \mathrm{L}$ of each dilution were seeded on GC plates in triplicates at the beginning of the assay (input) and after incubation at $37^{\circ} \mathrm{C}$ for 1,2 or 3 hours.

\section{Membrane Perturbation Assays: Sytox Green Staining}

Gonococci (FA1090 strain) were grown on GC agar plate overnight at $37^{\circ} \mathrm{C}$ with $5 \% \mathrm{CO}_{2}$-enriched atmosphere, and then subcultured in GC liquid medium from $\mathrm{OD}_{600 \mathrm{~nm}} 0.1$ until 0.3-0.4 for $4-5$ hours at $37^{\circ} \mathrm{C}$ shaking. Then, $\mathrm{OD}_{600 \mathrm{~nm}}$ was adjusted to 0.1 in new GC liquid medium and supplemented with NHS+/-OmCI $(25.3 \mu \mathrm{g} / \mathrm{mL}$ pre-treatment in undiluted NHS for $30 \mathrm{~min}$ on ice) and/or C4BP-IgM and/or antibiotics (concentrations indicated for each experiment), all diluted in $\mathrm{GVB}^{++}$. Bacteria were then incubated for 3 hours at $37^{\circ} \mathrm{C}$ with orbital shaking. Then, bacteria were harvested by centrifugation at $5000 \mathrm{xg}$, for $5 \mathrm{~min}$, washed once and incubated for $30 \mathrm{~min}$ at RT with $1 \mu \mathrm{M}$ of sytox green diluted in $\mathrm{HBSS}^{++}$, protected from the light. Internalized fluorescent signal was measured after washing bacteria once in $\mathrm{HBSS}^{++}$using Cytation5 reader: Excitation 488/Emission 525+/-20.

\section{Internalization of Fluorescent Antibiotics by Bacterial Cells}

Gonococci (strain FA1090 or FL29) were grown on GC agar plate overnight at $37^{\circ} \mathrm{C}$ in a $5 \% \mathrm{CO}_{2}$-enriched atmosphere. Bacteria were then subcultured on a new GC agar plate and incubated for 5 hours at $37^{\circ} \mathrm{C}$ in a $5 \% \mathrm{CO}_{2}$-enriched atmosphere. The culture was then harvested and re-suspended in $\mathrm{HBSS}^{++}$to an $\mathrm{OD}_{600 \mathrm{~nm}}$ of 2 . Some bacteria were treated with $50 \mu \mathrm{M}$ of efflux pump inhibitor (CCCP) for $30 \mathrm{~min}$ at RT. Bacteria were incubated with $20 \mu \mathrm{M}$ of Cipro-NBD or Roxi-NBD in the presence of $10 \% \mathrm{NHS}+/-\mathrm{OmCI}(25.3 \mu \mathrm{g} / \mathrm{mL}$ pre-treatment in undiluted NHS for 30 min on ice) supplemented with 5, 2.5 or $1.25 \mu \mathrm{g} / \mathrm{mL}$ of C4BP-IgM diluted in $\mathrm{GVB}^{++}$. Influx of fluorescent antibiotics in bacterial cells was measured by flow cytometry after 15,30 and $60 \mathrm{~min}$ of incubation at $37^{\circ} \mathrm{C}$ and one wash in $\mathrm{HBSS}^{++}$. In parallel, each sample was serially diluted in PBS and $10 \mu \mathrm{L}$ of each dilution were seeded on GC plates to estimate the survival of bacteria as $\mathrm{CFU} / \mathrm{mL}$ after overnight growth at $37^{\circ} \mathrm{C}$ in a $5 \% \mathrm{CO}_{2}$-enriched atmosphere. For confocal imaging, bacteria were incubated for 30 or $60 \mathrm{~min}$ with Cipro-NBD, and then stained for $5 \mathrm{~min}$ on ice with $5 \mu \mathrm{g} / \mathrm{mL}$ of FM4-64X diluted in $\mathrm{HBSS}^{++}$. After one wash in $\mathrm{HBSS}^{++}$, bacteria were spread onto a cover slip, dried and mounted using glass mounting media. LCM800 confocal microscope (Zeiss) with Airyscan mode was used to image the cells.

\section{Protein Synthesis Labeling via Click-iT Chemistry}

FA1090 strain was grown on GC agar plate overnight at $37^{\circ} \mathrm{C}$ in a $5 \% \mathrm{CO}_{2}$-enriched atmosphere. Bacteria were then subcultured in GC liquid medium from $\mathrm{OD}_{600 \mathrm{~nm}} 0.1$ until $\mathrm{OD}_{600 \mathrm{~nm}} 0.3-0.4$ for about 4 hours at $37^{\circ} \mathrm{C}$ on a rotary platform shaker. After washing in $\mathrm{HBSS}^{++}$at $37^{\circ} \mathrm{C}$, bacteria were adjusted to $\mathrm{OD}_{600 \mathrm{~nm}} 0.3$ in fresh GC liquid media supplemented with $100 \mu \mathrm{g} / \mathrm{mL}$ HPG and $5 \%$ NHS, with or without azithromycin $(0.25$ or $0.05 \mu \mathrm{g} / \mathrm{mL})$ and $5 \mu \mathrm{g} / \mathrm{mL}$ C4BP-IgM. After 4 hours at $37^{\circ} \mathrm{C}$, bacteria were harvested by centrifugation, fixed in $90 \%$ methanol during centrifugation at $5000 \mathrm{xg}$, for $15 \mathrm{~min}$ at $4^{\circ} \mathrm{C}$, then washed once in $\mathrm{HBSS}^{++}$and permeabilized in $0.5 \%$ Triton $\mathrm{X}-100 / \mathrm{HBSS}^{++}$for $30 \mathrm{~min}$ at RT. After centrifugation at $13000 \mathrm{xg}$, for $3 \mathrm{~min}$, bacterial pellet was washed twice in $1 \% \mathrm{BSA} \mathrm{HBSS}^{++}$and stained with $10 \mu \mathrm{M}$ AlexaFluor488 azide for $30 \mathrm{~min}$ at RT using copperdependent Click-iT reaction cocktail. After washes in 1\% BSA/ $\mathrm{HBSS}^{++}$, bacteria were analyzed by flow cytometry. In parallel, total protein content from bacterial cells was isolated on ice using RIPA buffer (50 mM Tris pH 7.4, $150 \mathrm{mM} \mathrm{NaCl,} \mathrm{1 \%} \mathrm{NP40,} \mathrm{0.5 \%}$ sodium deoxycholate) supplemented with protease inhibitors, and quantified with BCA method. Proteins $(10 \mu \mathrm{g})$ were loaded on SDS-PAGE gel for detection of fluorescently labeled and silver stained proteins.

\section{Statistics}

Statistical analyzes were performed using GraphPad Prism v8.0. Two-way ANOVA test with Sidak's multiple comparison was used to analyze the differences between samples in OD growth curve considering various concentrations of the antibiotics or in sytox green uptake considering various concentration of NHS or C4BP-IgM. Two-way ANOVA test with Tukey's multiple comparison was used to analyze the differences between samples in serum bactericidal assays or antibiotic internalization assays considering two or three time points, respectively. One-way ANOVA test was performed to analyze differences between samples from the reference (NHS) in complement deposition, membrane perturbation and Click-iT protein inhibition assays. Two-way ANOVA test with Dunnett's multiple comparison was used to analyze differences between samples from reference in serum bactericidal assays with NHS, C4BP-IgM and antibiotics. Significant differences are indicated with asterisks ${ }^{\star} \mathrm{p}<0.05,{ }^{* *} \mathrm{p}<0.01,{ }^{* *} \mathrm{p}<0.005,{ }^{* * *} \mathrm{p}<0.0001$.

\section{RESULTS}

\section{Normal Human Serum Reduces the MIC of Antibiotics}

We previously showed that N. gonorrhoeae FA1090 resists complement-mediated lysis in $10 \%$ NHS because it binds to 
the human complement inhibitor C4BP $(22,40)$. When grown overnight in gonococcal liquid medium, FA1090 showed the following MICs: spectinomycin, $16 \mu \mathrm{g} / \mathrm{mL}$; ciprofloxacin, 0.0019 $\mu \mathrm{g} / \mathrm{mL}$; and azithromycin $0.063 \mu \mathrm{g} / \mathrm{mL}$. The addition of $10 \%$ NHS together with antibiotics to FA1090 cultures significantly reduced $\mathrm{OD}_{600 \mathrm{~nm}}$ growth at concentrations equivalent or lower than MIC values for spectinomycin $(8 \mu \mathrm{g} / \mathrm{mL} p<0.0001 ; 16 \mu \mathrm{g} /$ $\mathrm{mL} p=0.0011)$ and ciprofloxacin $(0.0009 \mu \mathrm{g} / \mathrm{mL} p=0.0143)$, but not significantly for azithromycin. These observations suggested that complement could hamper the growth of gonococci at or just below the MIC of select antibiotics (Figures 1A-F).

\section{Complement Activation by C4BP-IgM Potentiates Killing of $\boldsymbol{N}$. gonorrhoeae by Antibiotics}

Previously, we showed that C4BP-IgM could trigger complement activation on the gonococcal surface and kill bacteria (22). We asked whether complement activation by C4BP-IgM could increase the activity of antibiotics. Initially, different concentrations of C4BP-IgM and antibiotics were tested to determine the lowest concentrations causing significant, but partial killing. C4BP-IgM at concentrations below $5 \mu \mathrm{g} / \mathrm{mL}$ did not significantly affect FA1090 survival in 10\% NHS (Supplementary Figure 1A). When complement-mediated lysis was blocked by OmCI (a C5 inhibitor that blocks formation of MAC), killing of bacteria was abrogated, confirming the complement-driven bactericidal activity of C4BP-IgM (Supplementary Figure 1A). Then, we identified concentrations of antibiotics which resulted in a partial killing of bacteria following incubation with or without serum for $2 \mathrm{~h}$ (spectinomycin, azithromycin and ceftriaxone) or $3 \mathrm{~h}$ (cefixime and ciprofloxacin). These concentrations were: $32 \mu \mathrm{g} /$ $\mathrm{mL}$ for spectinomycin, $250 \mathrm{ng} / \mathrm{mL}$ for azithromycin, $50 \mathrm{ng} / \mathrm{mL}$ for ceftriaxone, $3.75 \mathrm{ng} / \mathrm{mL}$ for ciprofloxacin and $12.5 \mathrm{ng} / \mathrm{mL}$ for cefixime (Supplementary Figures 1B-F). Using a C4BP-IgM concentration of $5 \mu \mathrm{g} / \mathrm{mL}$, we observed full killing of FA1090 bacteria after 2 hours of incubation with serum and
C
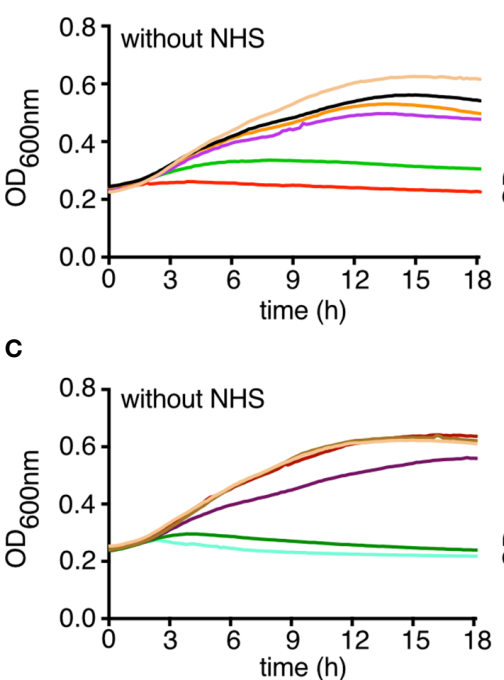

E

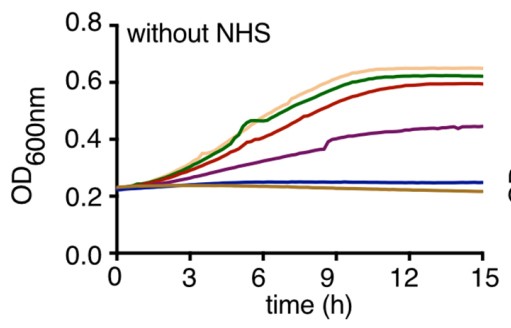

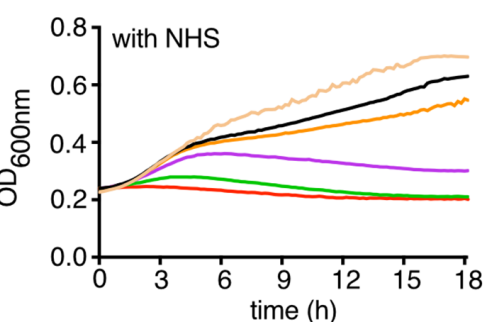
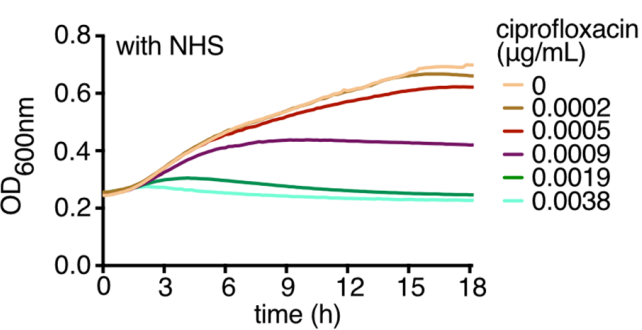

B

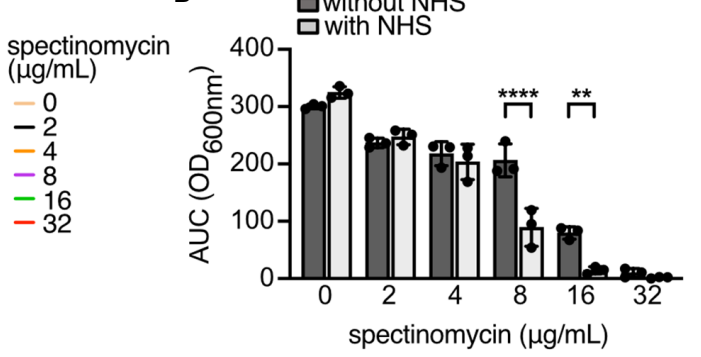

D

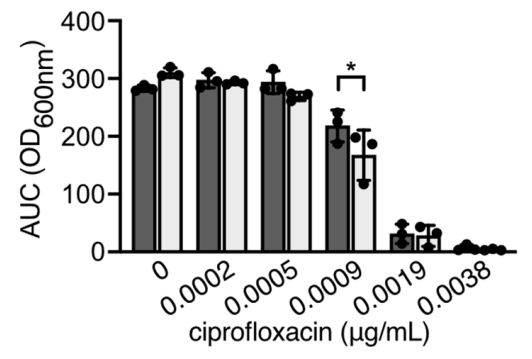

$\mathbf{F}$

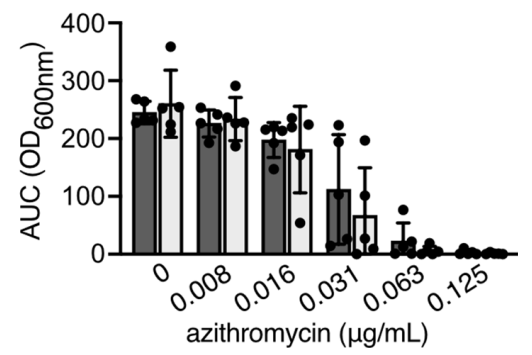

FIGURE 1 | NHS potentiates antibiotic killing of N. gonorrhoeae FA1090. (A, C, E) FA1090 gonococci were incubated at $37^{\circ} \mathrm{C}$ with orbital shaking overnight $+/$ $10 \%$ NHS and increasing concentrations of antibiotics: spectinomycin (A), ciprofloxacin (C) and azithromycin (E); growth of bacteria was monitored by measuring $\mathrm{OD}_{600 \mathrm{~nm}}$ every 10 min. (B, D, F) Area under the curve (AUC) of $\mathrm{OD}_{600 \mathrm{~nm}}$ were calculated for each concentration of antibiotics. Bars display mean+/-SD, with circles indicating each of 3 (A-D) or 5 (E, F) independent repeats. Differences among samples were compared using two-way ANOVA with Sidak's multiple-comparison test. ${ }^{\star} p<0.05,{ }^{\star \star} p<0.01,{ }^{\star \star \star *} p<0.0001$. 
spectinomycin, azithromycin and ceftriaxone (Figures 2A-C). Significant reductions in survival were also seen with the combinations of NHS, C4BP-IgM and ciprofloxacin or cefixime (Figures 2D, E). Blocking complement deposition by heat or with the complement-inhibitor OmCI abrogated killing of bacteria, suggesting that complement activation induced by C4BP-IgM potentiated antibiotic-mediated killing. While bacteria were completely killed following 2 hours of incubation with spectinomycin, azithromycin or ceftriaxone and C4BP-IgM plus NHS, modest survival at this time point was noted with ciprofloxacin and cefixime. Extension of the end-point of assays with ciprofloxacin and cefixime to 3 hours revealed a further drop in colony forming units (CFUs), suggesting slower killing kinetics with the latter antibiotics. Since partial killing was still evident with ciprofloxacin and cefixime even when complement was blocked with OmCI (Figures 2D, E), we speculated that components of human serum other than complement, i.e. endogenous antimicrobial peptides, may also have an effect on bacterial killing by antibiotics, as previously published (41). However, addition of the synthetic antimicrobial peptide LL-37 to NHS+C4BP-IgM did not enhance killing of bacteria, suggesting that LL-37 does not potentiate killing of gonococci by active complement (Supplementary Figure 2).

\section{Complement Activation Promoted by C4BP-IgM Induces Membrane Damage of $\boldsymbol{N}$. gonorrhoeae}

To elucidate how active complement potentiates gonococci killing by antimicrobials we investigated whether perturbation of the bacterial membrane by complement permitted antibiotic penetration. Even though FA1090 was resistant to MACmediated lysis in NHS (Supplementary Figure 3A; solid grey bars), NHS allowed influx of the cell impermeable reagent sytox green when incubated with increasing concentrations of active serum for 3 hours (Figure 3A). Blocking the complement cascade with the C5-inihbitor OmCI limited (but did not eliminate) sytox green entry into bacterial cells suggesting that MAC pores perturbed gonococcal membranes. As described previously (22), C4BP-IgM bound to FA1090 and efficiently promoted complement $\mathrm{C} 3$ fragment (as measured by $\mathrm{C} 3 \mathrm{~d}$ ) and MAC deposition on the bacterial surface in a dose-dependent manner (Figures 3B, C). Consequently, adding increasing concentrations of C4BP-IgM to serum correlated with increasing sytox uptake by gonococci, which was reduced to baseline levels in the presence of $\mathrm{OmCI}$, further confirming membrane perturbation by MAC (Figure 3D). We then explored membrane permeability in the presence of $10 \%$ NHS,
A

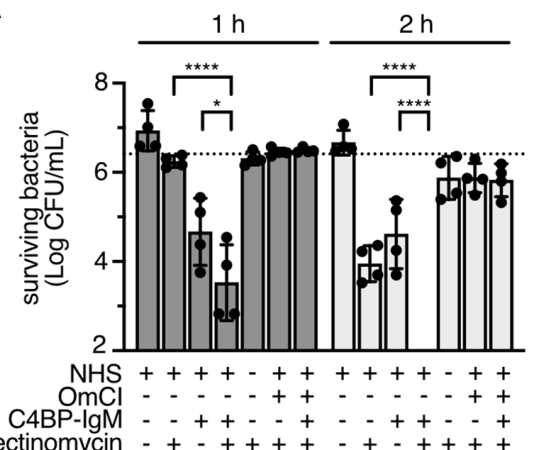

B

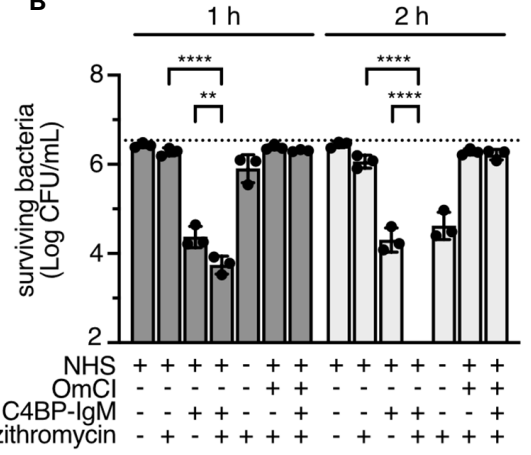

C

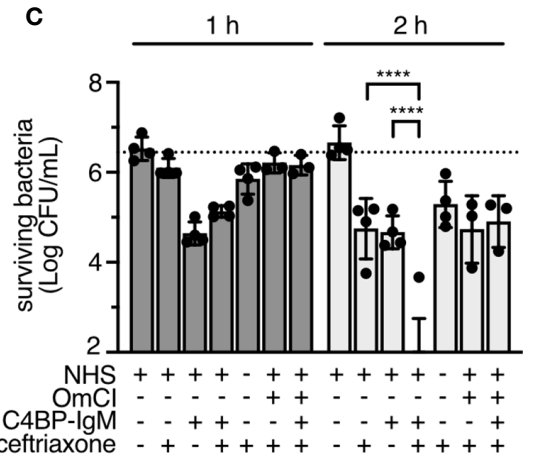

D

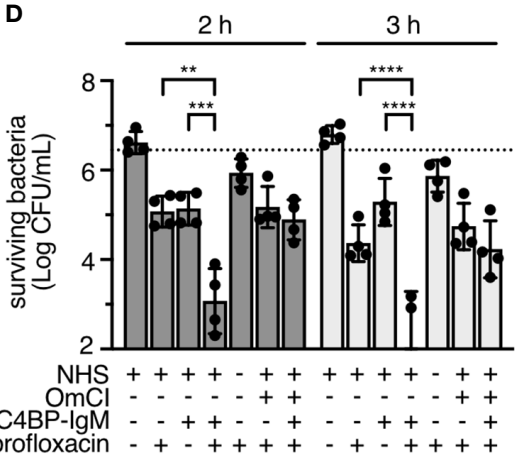

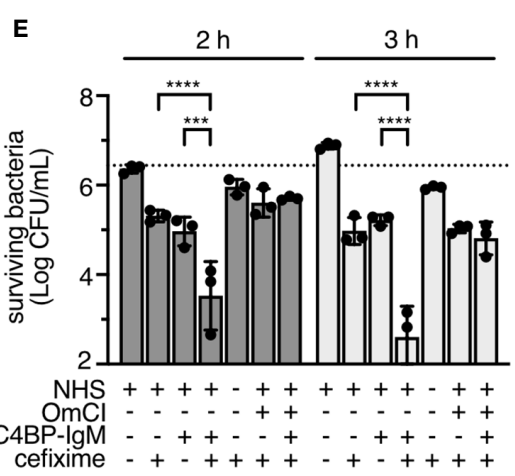

FIGURE 2 NHS and C4BP-IgM potentiates antibiotic killing of N. gonorrhoeae FA1090. (A-E) FA1090 gonococci were incubated for 1, 2 or 3 hours with 10\% $\mathrm{NHS}+/-O m C l$ supplemented with antibiotics (spectinomycin $32 \mu \mathrm{g} / \mathrm{mL}$, azithromycin $250 \mathrm{ng} / \mathrm{mL}$, ceftriaxone $50 \mathrm{ng} / \mathrm{mL}$, ciprofloxacin $3.75 \mathrm{ng} / \mathrm{mL}$, cefixime $12.5 \mathrm{ng} /$ $\mathrm{mL}$ ) in the presence or in the absence of $5 \mu \mathrm{g} / \mathrm{mL}$ of C4BP-IgM. Differences among samples were compared using two-way ANOVA with Tukey's multiple comparison test. Bars display mean+/-SD, with circles indicating 4 (A, C, D) or 3 (B, E) independent repeats. Horizontal dotted line indicates the starting CFUs of bacteria used in the assay. ${ }^{\star} \mathrm{p}<0.05,{ }^{\star \star} \mathrm{p}<0.01,{ }^{\star \star \star} \mathrm{p}<0.005,{ }^{\star \star \star *} \mathrm{p}<0.0001$. 


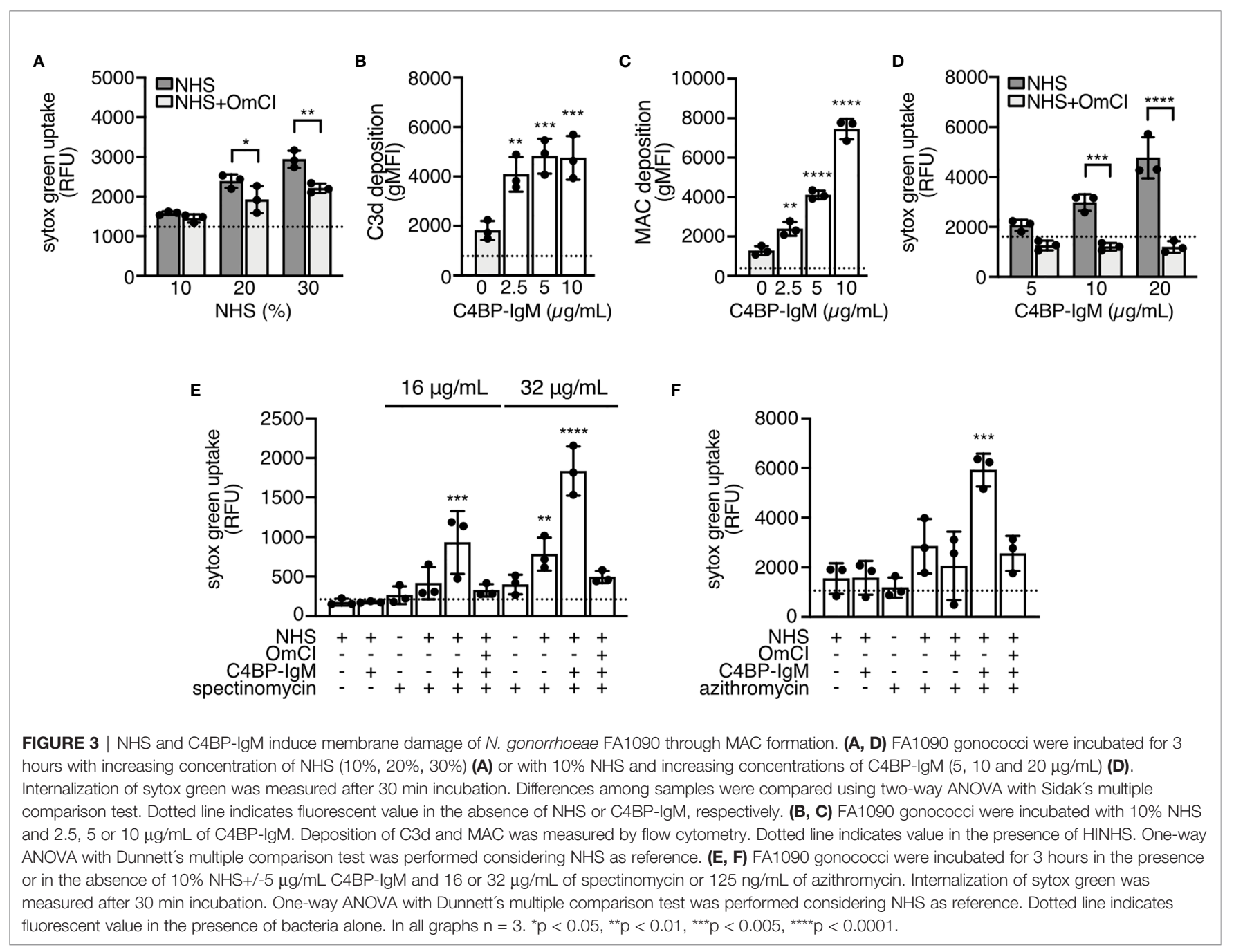

$5 \mu \mathrm{g} / \mathrm{mL}$ of C4BP-IgM and antibiotics (spectinomycin or azithromycin); the reaction mixtures resulted in only partial bacterial killing. When C4BP-IgM or antibiotics were added singly to NHS they induced minor ingress of the fluorescent dye into FA1090 cells. Interestingly, the presence of C4BP-IgM in NHS together with each antibiotic significantly increased sytox green influx into FA1090 gonococci, indicating substantially greater membrane perturbation (Figures 3E, F). Increasing concentrations of spectinomycin added to $10 \%$ NHS resulted in accumulation of fluorescence inside bacteria, further indicating that complement activation plays a key role in sensitizing bacteria to antibiotics (Supplementary Figure 3B).

\section{Antibiotic Influx Into Bacterial Cells Is Promoted by Complement Activation and Further Enhanced by C4BP-IgM}

The availability of fluorophore (NBD)-labeled versions of ciprofloxacin and roxithromycin (a macrolide, related to azithromycin) $(37,38)$ allowed us to study whether complement activation promoted the influx of antibiotics. Cipro-NBD and Roxi-NBD uptake by gonococci in the presence or in the absence of $10 \%$ NHS and 5 (Cipro-NBD) or $2.5 \mu \mathrm{g} / \mathrm{mL}$ (Roxi-NBD) of C4BP-IgM, was monitored over time. Cipro-NBD $(20 \mu \mathrm{M})$ was efficiently internalized by FA1090 after 60 min, as shown in the confocal microscopy images in Figure 4A where bacterial membranes were stained with the lipophilic probe FM4-64FX. NHS increased both Cipro-NBD and Roxi-NBD influx at $60 \mathrm{~min}$, which was significantly decreased when the C5 was blocked with OmCI (Figures 4B, D). Interestingly, the presence of C4BP-IgM, as enhancer of complement activation in NHS, augmented the amount and accelerated the internalization of both probes in FA1090 cells as early as 30 min of incubation. Uptake of the fluorescent antibiotics (which retain antimicrobial activity) resulted in the killing of bacteria over time (Figures 4C, E), which was significantly enhanced when serum plus C4BP-IgM was supplemented with Roxi-NBD (Figure 4E). Taken together, these data suggest that the fusion protein boosts complementmediated membrane permeabilization, which promotes antibiotic influx into bacterial cells resulting in cell death. 
A

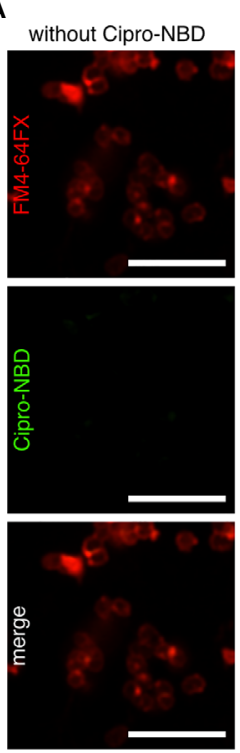

$\mathbf{F}$
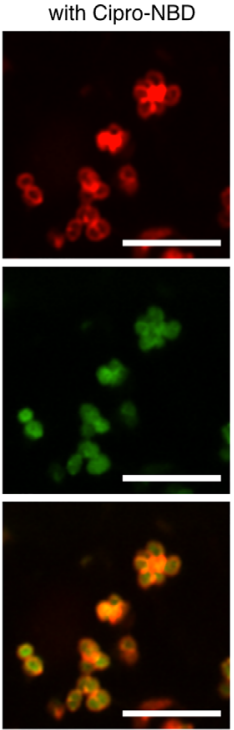

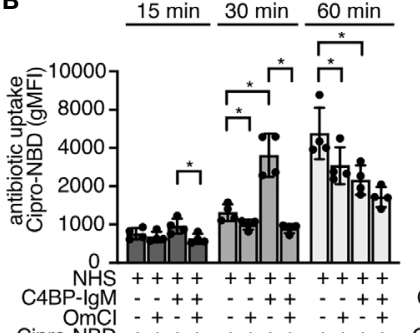

Cipro-NBD ++++++++++++
C

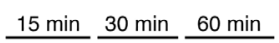

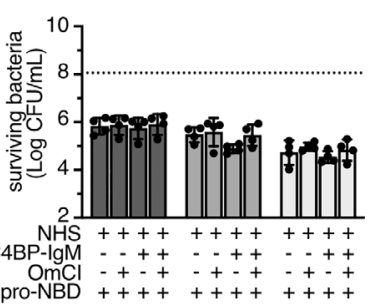

D

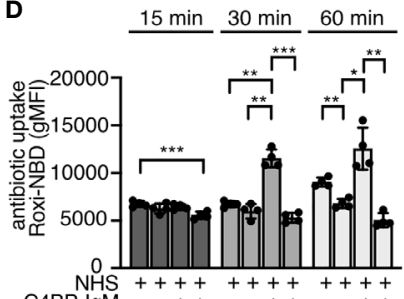

C4BP-lgM $:++\quad:++:-+2$

OmCl $+++\cdots++\cdots++$

E

E

E $\quad 15 \mathrm{~min} 30 \mathrm{~min} .60 \mathrm{~min}$
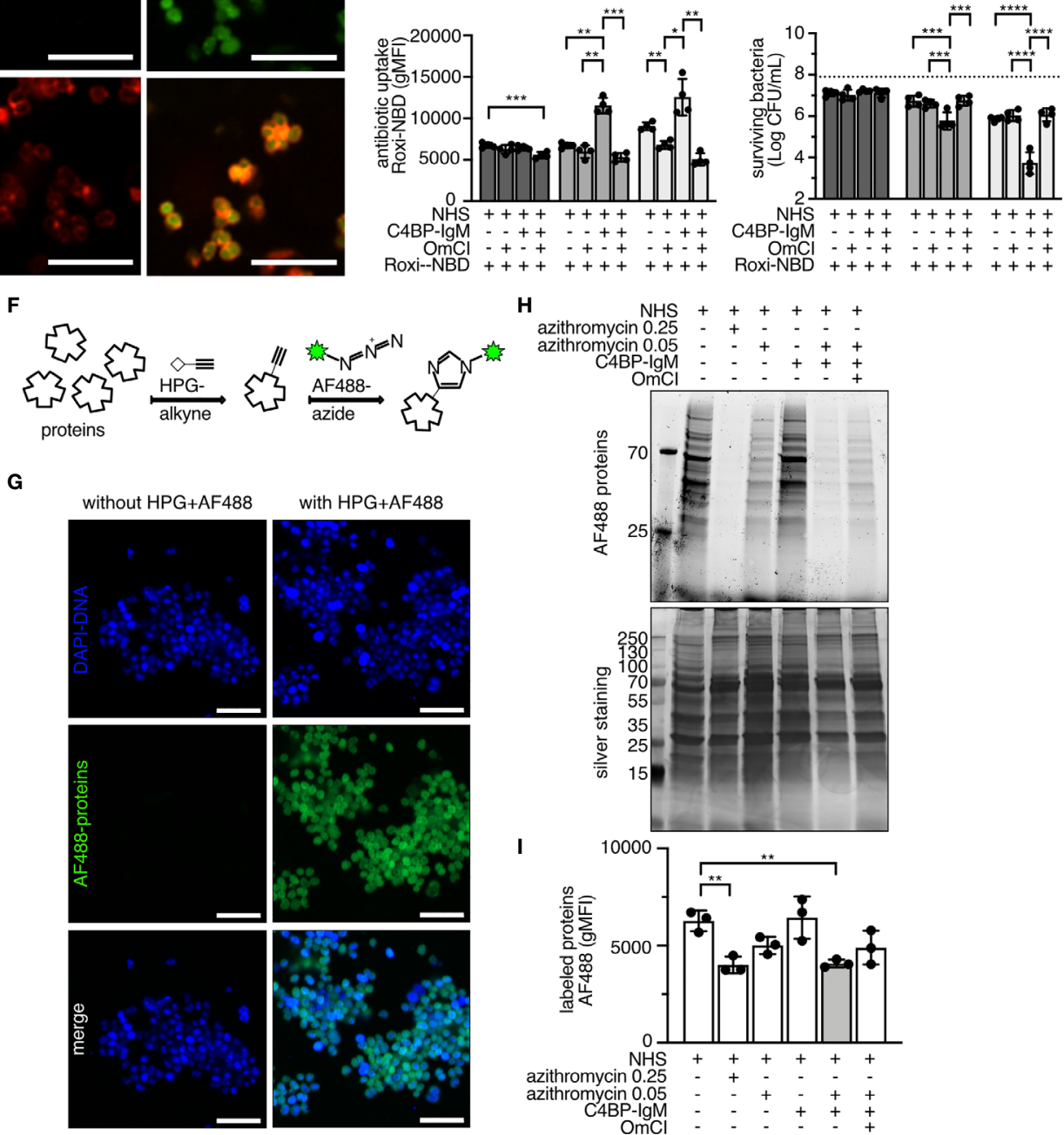

G

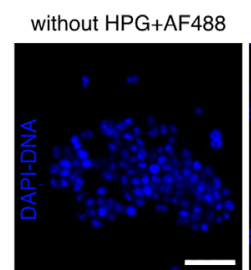

with $\mathrm{HPG}+\mathrm{AF} 488$
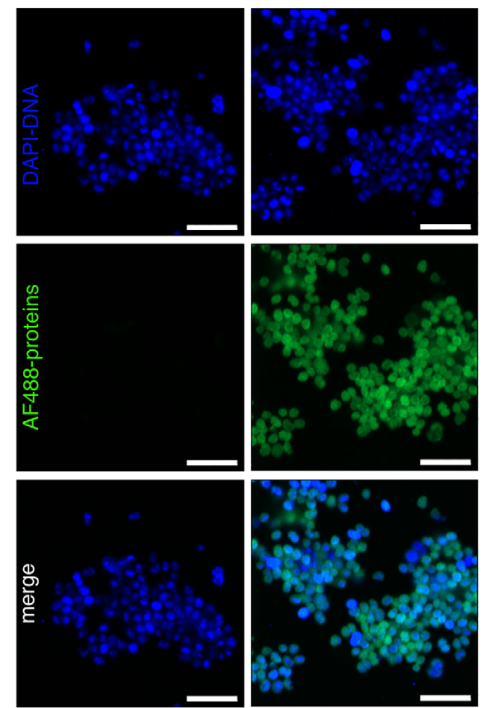

FIGURE 4 | NHS and C4BP-IgM promote influx and intracellular activity of antibiotics in N. gonorrhoeae. (A) Airyscan confocal fluorescent microscopy of live FA1090 labeled with FM4-64FX membrane dye and treated with or without $20 \mu \mathrm{M}$ of Cipro-NBD for 60 min at $37^{\circ} \mathrm{C}$. Scale bar: $5 \mu \mathrm{m}$. (B-E) FA1090 gonococci were incubated with $20 \mu \mathrm{M}$ of Cipro-NBD or Roxi-NBD for 15,30 and 60 min at $37^{\circ} \mathrm{C}$ in the presence of $10 \% \mathrm{NHS}+/-\mathrm{OmCl}$ with or without 5 (Cipro-NBD) or 2.5 $\mu \mathrm{g} / \mathrm{mL}$ (Roxi-NBD) of C4BP-lgM. Internalized fluorescent antibiotic is measured as fluorescent signal (gMFI). Survival of bacteria is indicated as Log(CFU/mL) with horizontal dotted line referring to average of $\mathrm{Log}(\mathrm{CFU} / \mathrm{mL})$ of bacteria recovered in the absence of probes. Bars display mean+/-SD with circles indicating independent repeats; $n=4$. Two-way ANOVA with Tukey's multiple comparison was performed to analyze differences among samples. ${ }^{\star} p<0.05$, ${ }^{\star \star} p<0.01$, ${ }^{* \star *} \mathrm{p}<0.005,{ }^{* \star * *} \mathrm{p}<0.0001$. (F) Schematic representation of AF488-labeling of newly synthesized proteins via Click-iT chemistry. (G) Airyscan confocal fluorescent microscopy of live FA1090 labeled with DAPI DNA dye after 4 hours incubation with $100 \mu \mathrm{g} / \mathrm{mL}$ HPG-alkyne at $37^{\circ} \mathrm{C}$ followed by $10 \mu \mathrm{M}$ AF488-azide via Click-iT chemistry. Scale bar: $5 \mu \mathrm{m}$. (H, I) FA1090 gonococci were incubated for 4 hours at $37^{\circ} \mathrm{C}$ in the presence of $100 \mu \mathrm{g} / \mathrm{mL} \mathrm{HPG}-\mathrm{alkyne}, 5 \%$ NHS+/-5 $\mu \mathrm{g} / \mathrm{mL} \mathrm{C} 4 \mathrm{BP}-$ IgM and 0.25 or $0.05 \mu \mathrm{g} / \mathrm{mL}$ of azithromycin. Newly synthesized proteins were labeled with $10 \mu \mathrm{M}$ AF488-azide via Click-iT chemistry and detected on SDS-PAGE in fluorescent or by silver staining $\mathbf{( H )}$ and in flow cytometry $\mathbf{( I )}, \mathrm{n}=3$. One-way ANOVA with Dunnett's multiple comparison test was performed considering NHS as reference. ${ }^{\star} p<0.05,{ }^{* \star} p<0.01,{ }^{\star \star *} p<0.005,{ }^{* \star *} p<0.0001$. 


\section{Antibiotic Activity Inside Bacterial Cells Increases When Complement Is Activated by C4BP-IgM}

Another method to verify the internalization of macrolides into the cells is to evaluate their effect on protein synthesis. Azithromycin is a ring-expanded macrolide derivative, which permeates into the cell interior through the lipid bilayer. Once inside the bacterium, azithromycin interacts with the $50 \mathrm{~S}$ ribosomal subunit and inhibits protein synthesis, which in turn arrests bacterial growth. To monitor protein synthesis and azithromycin inhibitory activity, we used the Click-IT technology based on the incorporation of homopropargylglycine (HPG), an amino acid analog of methionine containing an alkyne moiety, which was then detected by the AF488 conjugated-azide through direct coupling (Figure 4F). After 4 hours of incubation with the modified amino acid, the majority of the proteins present inside bacterial cells became fluorescently labeled, as a result of incorporation of the exogenous amino acid supplemented in the medium (Figure 4G). Protein synthesis was not significantly altered in the presence of NHS with or without C4BP-IgM at sub-bactericidal concentrations, or in the presence of concentrations of azithromycin $(0.05 \mu \mathrm{g} / \mathrm{mL})$ in NHS that caused only partial killing (Figures $\mathbf{4 H}$, I). Interestingly, when azithromycin $(0.05 \mu \mathrm{g} / \mathrm{mL})$ was added to serum containing C4BP$\operatorname{IgM}$, the quantity of fluorescent proteins significantly decreased indicating that the inhibitory activity of azithromycin on protein synthesis increased when complement activation was boosted by C4BP-IgM. It is worth noting that a 5-fold higher concentration of azithromycin $(0.25 \mu \mathrm{g} / \mathrm{mL})$ was required to obtain an equivalent level of inhibition of protein synthesis seen in the presence of C4BP-IgM. Additionally, adding OmCI to the mixture with NHS+C4BP-IgM and azithromycin $0.05 \mu \mathrm{g} / \mathrm{mL}$ partially restored protein synthesis to levels observed with azithromycin $(0.05 \mu \mathrm{g} / \mathrm{mL})$ in NHS, further confirming the impact of complement-mediated MAC pores in increasing the activity of azithromycin.

\section{Complement Activation Through C4BP- IgM Restores Antibiotic Susceptibility of Two Azithromycin-Resistant \\ N. gonorrhoeae Strains}

Encouraged by the results obtained with the laboratory strain FA1090, we then explored the activity of complement in combination with antibiotics on two selected clinical isolates (FL29 and SA94) of N. gonorrhoeae, which are resistant to azithromycin (MIC by Etest $=4 \mu \mathrm{g} / \mathrm{mL}$ ) (23). These clinical isolates were chosen because their mechanism of azithromycin resistance was overexpression of the MtrC-MtrD-MtrE efflux pump caused by a mosaic mtrRCDE operon that we hypothesized could be overcome by enhanced macrolide entry facilitated by MAC. Firstly, we verified that C4BP-IgM bound to both strains and promoted complement-mediated killing (Supplementary Figures $4 \mathrm{~A}-\mathrm{C}$ ). Concentrations of C4BP-IgM that resulted in only partial killing for each strain were identified to be $0.6 \mu \mathrm{g} / \mathrm{mL}$ for FL29 and $0.16 \mu \mathrm{g} / \mathrm{mL}$ for SA94. Both strains survived completely when incubated for 2 hours with concentrations of azithromycin up to $16 \mu \mathrm{g} / \mathrm{mL}$ (Figures 5A-D). The presence of NHS significantly decreased survival of bacteria in the presence of azithromycin above $1 \mu \mathrm{g} / \mathrm{mL}$. Notably, a further significant reduction in survival for both strains was observed with supplementation of C4BP-IgM at all concentrations of azithromycin tested in a time dependent manner. In a parallel control reaction, azithromycin at $16 \mu \mathrm{g} / \mathrm{mL}$ completely killed strain FA1090. Taken together, these results suggest an additive effect between C4BP-IgM and azithromycin in killing gonococci.

To verify the contribution of complement activation in augmenting killing by $4 \mu \mathrm{g} / \mathrm{mL}$ azithromycin, we then tested the effect of C4BP-IgM in serum that was inactivated by heating at $56^{\circ} \mathrm{C}$ or with $\mathrm{OmCI}$. Interestingly, while heat inactivation of human serum completely rescued bacteria survival both in the presence or in the absence of the fusion protein, complement inhibition by OmCI only partially prevented bacterial killing induced by C4BP-IgM, suggesting the presence of additional heat-labile bactericidal components in serum that potentiate azithromycin activity on gonococci (Figures 5E, F). C3a generated by complement activation also shows bactericidal activity (42). To test whether C3 fragments generated during complement activation by C4BP-IgM facilitated killing by azithromycin in killing gonococci, we used the selective C3 inhibitor compstatin (Cp40) (39). Blocking C3 cleavage with $50 \mu \mathrm{M}$ of $\mathrm{Cp} 40$ abrogated C4BP-IgM-mediated killing (Supplementary Figure 4B), and protected gonococci from killing by the combination of serum and azithromycin to a significantly greater extent than OmCI (Figures 5G, H). These results indicate that $\mathrm{C} 4 \mathrm{BP}$-IgM mediated complement activation through the level of $\mathrm{C} 3$ activation may also sensitize bacteria to macrolides.

\section{C4BP-IgM Promotes Antibiotic Entry Into the Cell of Azithromycin-Resistant N. gonorrhoeae Strain}

To show that active complement mediates internalization of antibiotics in gonococci, uptake of NBD-labeled antibiotics was monitored in the azithromycin-resistant strain FL29. Treatment of bacteria with the efflux pump inhibitor CCCP, which disrupts the proton gradient driving efflux pumps (overactivation of the MtrC-MtrD-MtrE efflux pump in FL29 causes the macrolide resistance and increases its MIC to ciprofloxacin), resulted in a significant influx of both Cipro-NBD and Roxi-NBD in a time dependent manner (Figures 6A, C). However, survival of bacteria was barely affected, which might suggest that inhibition was not stably maintained over time (Figures 6B, D). The presence of NHS together with C4BP-IgM significantly augmented internalization of the antibiotic-NBD probes overtime. Consequently, survival of bacteria was significantly hampered when incubated with both fluorescent antibiotics and NHS supplemented with the fusion protein (Figures 6B, D). Complement inhibition by OmCI completely abrogated influx of both fluorescent antibiotics into gonococci, resulting in survival of bacteria. Confocal images of live FL29 gonococci treated with Cipro-NBD in the absence of NHS for $30 \mathrm{~min}$ revealed that only few bacteria contained the fluorescent probe, 
A

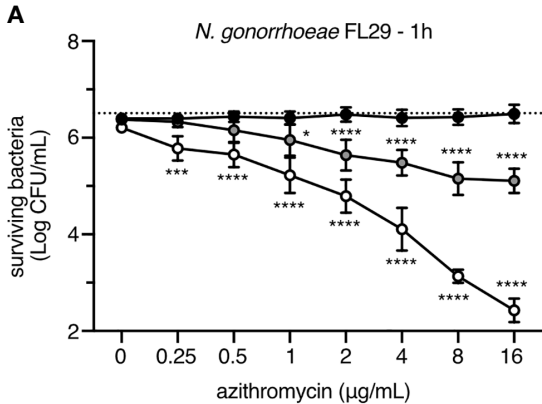

C

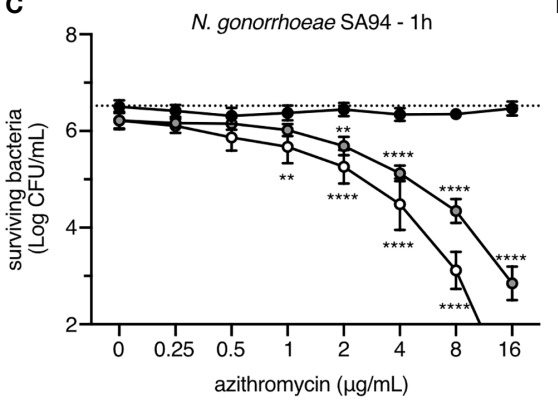

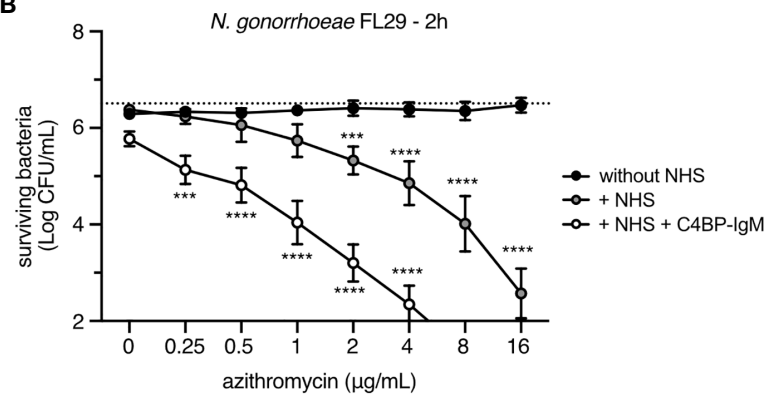

D

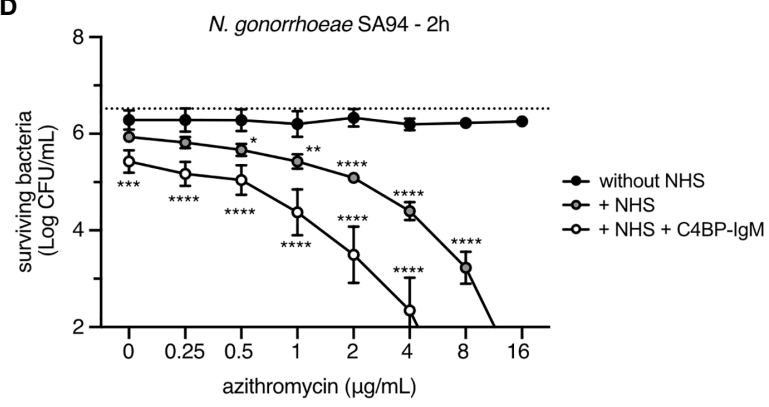

E

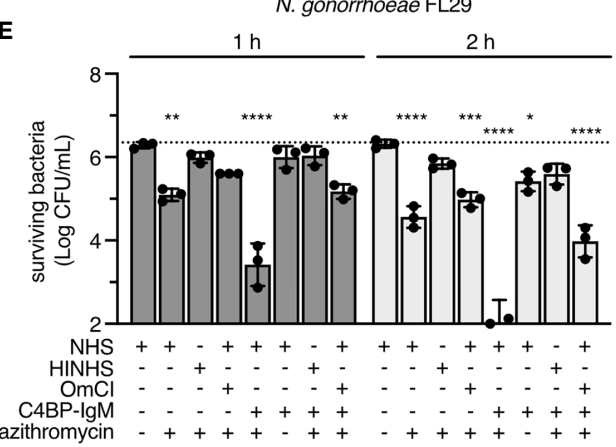

$\mathbf{F}$

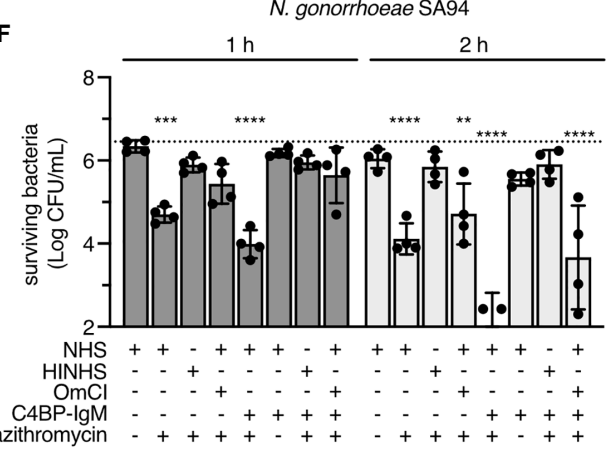

G

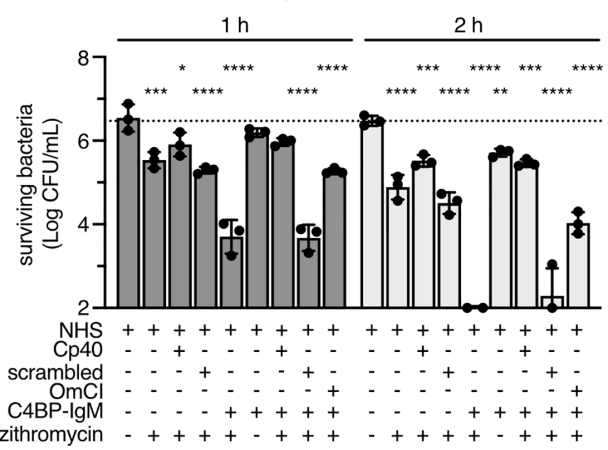

H

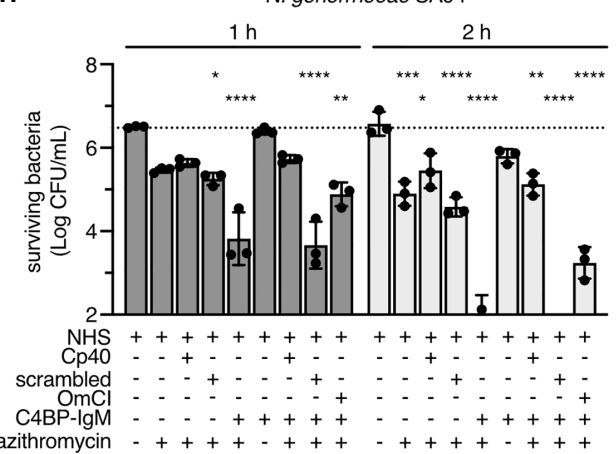

FIGURE 5 | Complement activation in NHS cooperates with antibiotics in killing two azithromycin-resistant strains of N. gonorrhoeae. FL29 (A, B) and SA94 (C, D) gonococci were incubated for 1 and 2 hours with increasing concentrations of azithromycin in the presence or in the absence of $10 \% \mathrm{NHS}$ and $0.6 \mu \mathrm{g} / \mathrm{mL}$ or 0.16 $\mu \mathrm{g} / \mathrm{mL}$ of C4BP-lgM, respectively. At each azithromycin concentration, differences from samples without NHS were compared using two-way ANOVA with Dunnett's multiple comparison test. FL29 (E, G) and SA94 (F, H) gonococci were incubated for 1 or 2 hours with $10 \% \mathrm{NHS}$, HINHS or NHS+OmCl or NHS+Cp40 (50 $\mu$ M) supplemented with $4 \mu \mathrm{g} / \mathrm{mL}$ of azithromycin, in the presence or in the absence of $0.6 \mu \mathrm{g} / \mathrm{mL}$ or $0.16 \mu \mathrm{g} / \mathrm{mL}$ of C4BP-lgM, respectively. Scrambled peptide is used as irrelevant protein for Cp40-treated samples. Two-way ANOVA with Dunnett's multiple comparison test was performed considering NHS as reference. Bars display mean+/-SD, with circles indicating $4(\mathbf{A}-\mathbf{D}, \mathbf{F})$ and $3 \mathbf{( E ,}, \mathbf{G}, \mathbf{H})$ independent repeats. In all graphs horizontal dotted line refers to the starting number of bacteria used in the assay. ${ }^{\star} p<0.05,{ }^{* \star} p<0.01,{ }^{* \star *} p<0.005,{ }^{* \star *} p<0.0001$. 
A $\underline{15 \mathrm{~min}} \stackrel{30 \mathrm{~min}}{60 \mathrm{~min}}$

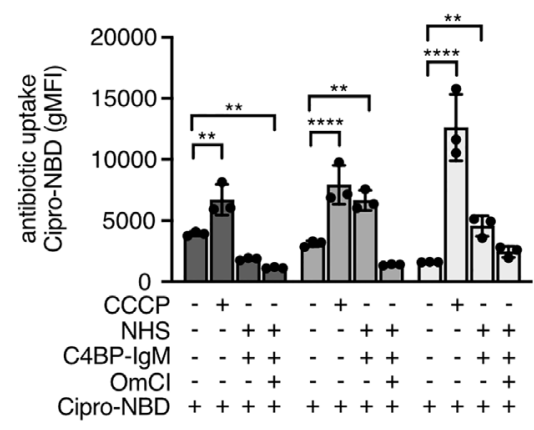

C

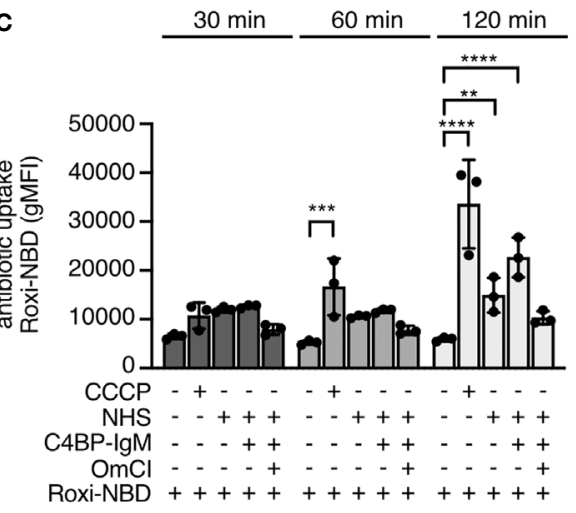

E
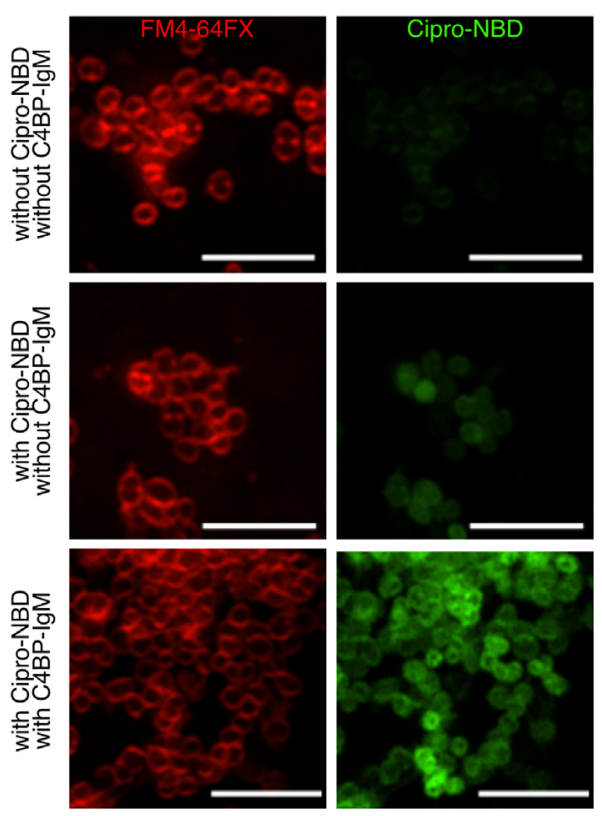

B

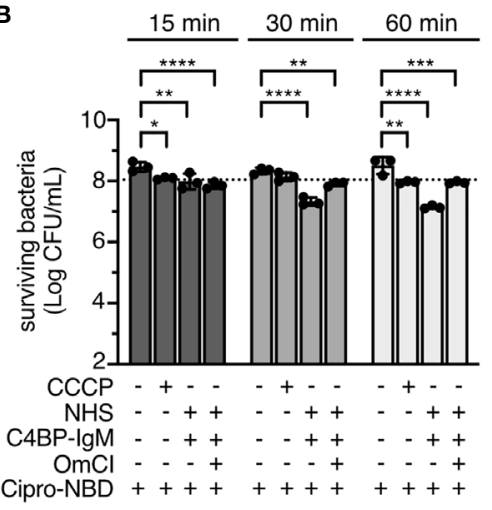

D $\quad 30 \mathrm{~min} \quad 60 \mathrm{~min}$
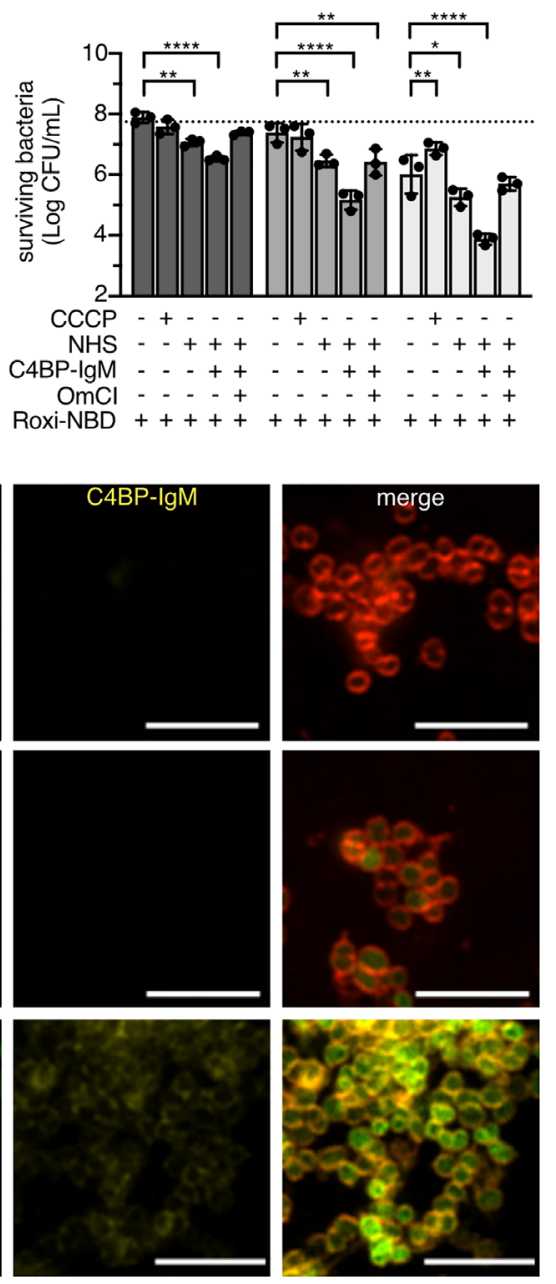

FIGURE 6 | NHS and C4BP-IgM promote internalization of antibiotics in N. gonorrhoeae FL29. FL29 gonococci were incubated with $20 \mu \mathrm{M}$ of Cipro-NBD for 15, 30 and $60 \mathrm{~min}(\mathbf{A}, \mathbf{B})$ or $20 \mu \mathrm{M}$ of Roxi-NBD for 30,60 and $120 \mathrm{~min}(\mathbf{C}, \mathbf{D})$ at $37^{\circ} \mathrm{C}$ in the presence of $10 \% \mathrm{NHS}+/-\mathrm{OmCl}$ with or without $50 \mu \mathrm{M}$ of CCCP or 1.25 $\mu \mathrm{g} / \mathrm{mL}$ of C4BP-lgM. Internalized fluorescent antibiotic is measured as fluorescent signal (gMFI). Survival of bacteria is indicated as Log(CFU/mL), and horizontal dotted line indicates the average of $\mathrm{Log}(\mathrm{CFU} / \mathrm{mL})$ of bacteria recovered in the absence of probes. Bars display mean+/-SD with circles indicating independent repeats; $\mathrm{n}=3$. Two-way ANOVA with Dunnett's multiple comparison test was performed to analyze differences of samples in comparison to bacteria+probe. ${ }^{*} \mathrm{p}<$ $0.05,{ }^{\star \star} \mathrm{p}<0.01,{ }^{* \star *} \mathrm{p}<0.005,{ }^{\star \star \star *} \mathrm{p}<0.0001$. (E) Airyscan confocal fluorescent microscopy of live FL29 labeled with FM4-64FX membrane dye and treated with or without $20 \mu \mathrm{M}$ of Cipro-NBD for $30 \mathrm{~min}$ at $37^{\circ} \mathrm{C}$ in the presence or in the absence of NHS and C4BP-lgM, the latter detected using an Alexa Fluor-647 labeled antihuman lgM. Scale bar: $5 \mu \mathrm{m}$. 
providing evidence that most cells efficiently removed the drug by efflux pumps that are overexpressed in this strain. Of note, when bacterial cells were coated with C4BP-IgM, almost all cells were stained with the fluorescent green probe, suggesting that the fusion protein helped overcome the hyperactive efflux pumps and promoted drug influx (Figure 6E).

\section{DISCUSSION}

Antimicrobial resistance has emerged worldwide in many pathogenic bacteria, including $N$. gonorrhoeae. The recent treatment failures of ceftriaxone, either as monotherapy or even in combination with azithromycin highlight the urgent need to develop alternative therapeutic approaches against gonorrhea (7, 15). We previously showed the efficacy of C4BP-IgM fusion protein in eliminating gonococci through complement-mediated lysis (22). In the present study we propose using C4BP-IgM as an antimicrobial adjuvant for the treatment of gonococcal infections. The ability of C4BP-IgM to increase the efficacy of antimicrobials relies on the ability of the fusion protein to boost complement activation on the microbial surface. Complement-induced MAC pores facilitate uptake of antimicrobials, which in turn enhances their intracellular concentration and activity. In particular, our results demonstrate that C4BP-IgM potentiates the activity of azithromycin against two macrolide-resistant strains carrying $m t r$ efflux pump mutations. We therefore propose C4BP-IgM as an alternative strategy to bypass the bacterial membrane barrier and restore the activity of antibiotics against resistant strains with hyperactive efflux pumps. We acknowledge that enhanced penetration of antibiotics may not overcome resistance in strains where mutations abrogate the binding of antibiotics to their targets (e.g., mutations in the $23 \mathrm{~S}$ rRNA of the $50 \mathrm{~S}$ ribosomal subunit for azithromycin and GyrA for quinolones).

Early vaccine development efforts against $N$. gonorrhoeae were not successful in large part because antigenic variability of candidate vaccine antigens led to strain-specific immunity (43, 44). Effective antimicrobial treatment remains an essential element in the management and control of gonococcal infections. However, the rapid development of AMR in gonococci has repeatedly compromised treatment (17). The combination of antibiotics with membrane permeabilizing agents as adjunctive treatments may be a viable antibacterial approach (45). Such agents increase bacterial membrane fluidity or reduce efflux of drugs. Numerous examples of this approach have been described for gram-negative bacteria, including use of: polymyxins (29), the anti-protozoal drug pentamidine (46), the human $\alpha$-lactalbumin-oleic acid complex HAMLET (47), and natural or synthetic inhibitors of efflux pumps (48). Interestingly, ex vivo assays using human blood showed that human complement activation on the outer membrane of bacteria sensitizes some gram-negative strains to antibiotics otherwise specific for gram-positive bacteria (32). Given its ability to insert MAC pores into the bacterial membrane, we hypothesized that the C4BP-IgM fusion protein would augment antimicrobial activity in a similar way to the aforementioned permeabilizing agents. Indeed, C4BP-IgM disrupts gonococcal membranes in the presence of human active serum and promotes the uptake of antibiotics. Intracellular accumulation of the drugs resulted in enhanced antimicrobial activity that accelerated gonococcal killing. Rapid and complete killing limits the opportunity for resistant organisms to emerge. Several cell permeabilizing agents also act on eukaryotic cells, which could result in host toxicity. C4BP-IgM has an advantage because it neither binds to nor enhances complement deposition on human cells, as we showed previously (22). Other molecules that enhance complement activation on bacteria may also enhance activity of antimicrobials. As an example, fusion proteins which combine bacterial binding domains of FH with constant portions of immunoglobulins $(49,50)$ could also function as membrane permeabilizers in a manner similar to C4BP-IgM.

Factors in serum other than complement may contribute to killing of some gram-negative bacteria independently of MAC (51), therefore we cannot exclude the cooperation of other antibacterial peptides in NHS in killing gonococci by ciprofloxacin and azithromycin. Interestingly, we observed that C3 fragments generated by C4BP-IgM in serum cooperates with antibiotics to kill gonococci. A previous study showed that C3a possesses bactericidal properties (42). While blocking MAC formation with the $\mathrm{C} 5$ inhibitor OmCI only partially rescued killing of gonococci by the combination of azithromycin, NHS and C4BP-IgM, heat inactivation of NHS (blocks C3 deposition) or the addition of compstatin (blocks C3 cleavage) to NHS abrogated killing. These data suggest that antimicrobial activities upstream in the complement cascade - likely C3 activation - may also augment killing by antibiotics.

C4BP-IgM triggers rapid complement activation, which is essential to form MAC pores. A recent study revealed that MAC pores are flexible toroid-shaped holes with an inner diameter of about $30 \AA(3 \mathrm{~nm})$ that adopt either an open or a closed conformation (52). Upon complement activation, the MAC pores may provide additional channels for antibiotics to reach their targets in the intracellular compartments of bacteria. Thus, molecular mechanisms that reduce resistance to antibiotics are likely the result of a dual effect on membrane disruption: more antibiotic entry through MAC pores and less drug efflux because of reduced efflux pump activity.

The efflux pump complex expressed by the $m \operatorname{tr} C D E$ operon of $N$. gonorrhoeae expels various hydrophobic agents including antibiotics and antibacterial peptides from cells. Gonococci possess transcriptional control systems to modulate expression of their efflux pumps (53). This could result in increased bacterial proliferation before effective antibiotic therapy can be initiated when overexpression of $m t r$ genes protects them from these agents. Reducing the dosage of the antibiotics using adjunctives such as C4BP-IgM could limit the selection of mutants overexpressing MtrC-MtrD-MtrE efflux pumps or the production of otherwise silent MDR transporters. Combination treatment also may limit the side effects of single agents that would otherwise be used in larger doses, while potentiating the antimicrobial attack towards different targets. Interestingly, despite the fact that some AMR determinants may increase bacterial survival and fitness 
during infection (54), overexpression of the MtrC-MtrD-MtrE efflux pump can result in a fitness cost during cervical colonization (55).

A limitation of our approach is that C4BP-IgM as 'permeabilizing agent' for antibiotics would work only on those bacteria that are able to bind C4BP, which is about $45 \%$ of surveyed strains $(22,40)$. Nevertheless, our results provide proofof-principle that triggering complement activation can restore susceptibility of gonococci with overactive MtrC-MtrD-MtrE efflux pumps to macrolides.

In this study we demonstrated the adjuvant activity of C4BPIgM fusion protein for certain antibiotics previously or currently used to treat gonorrhea. Therefore, C4BP-IgM could be considered for topical administration at the site of infection (for example, intravaginally) in conjunction with systemically administered antibiotics.

\section{CONCLUSION}

In conclusion, our data provide proof-of-principle to enhance complement activation on microbes, which in turn potentiates antibiotic efficacy and restores susceptibility to select resistant strains. This approach offers an innovative option to combat the global problem of antimicrobial resistance.

\section{DATA AVAILABILITY STATEMENT}

The raw data supporting the conclusions of this article will be made available by the authors, without undue reservation.

\section{ETHICS STATEMENT}

The studies involving human participants were reviewed and approved by the ethical committee in Lund (Permit 2019/14). The patients/participants provided their written informed consent to participate in this study.

\section{AUTHOR CONTRIBUTIONS}

$\mathrm{SB}, \mathrm{KM}, \mathrm{MU}, \mathrm{SR}$, and $\mathrm{AB}$ designed research studies and analyzed data. SB and KM conducted experiments. MS and MAB supplied fluorescent probes and gave technical advice. MU and MLB provided strains and data for gonococcal clinical isolates. JP provided the purified LL-37. SB, SR, and AB wrote the manuscript. All authors contributed to the article and approved the submitted version.

\section{FUNDING}

The study was supported by grants from Swedish Research Council (2018-02392), Torsten Söderberg Foundation (MT3/18),
The Österlund Foundation (to $\mathrm{AB}$ ) as well as grants from Sten K. Johnsons Foundation (2019), the Tore Nilson's Foundation (2019-00750), the Royal Physiographic Society of Lund (40824), the O. E. och Edla Johanssons Foundation (2020 and 2021), The Lars Hierta Memorial Foundation (FO2020-0257), Längmanska kulturfonden (BA20-1272, BA21-0550) and Clas Groschinskys Fondation (M21106) (to SB). MS was supported by an Australian Postgraduate Award and an Institute for Molecular Biosciences Research Advancement Award. SR was supported by National Institutes of Health grants R01 AI32296 and R44 AI147930.

\section{ACKNOWLEDGMENTS}

The authors deeply thank John D. Lambris, University of Pennsylvania, for kindly providing the C3 inhibitor compstatin.

\section{SUPPLEMENTARY MATERIAL}

The Supplementary Material for this article can be found online at: https://www.frontiersin.org/articles/10.3389/fimmu.2021. 726801/full\#supplementary-material

Supplementary Figure 1 | Subtotal concentrations of C4BP-IgM and antibiotics on N. gonorrhoeae. FA1090 gonococci were incubated with increasing concentrations of C4BP-IgM (A) or of spectinomycin, azithromycin, ceftriaxone, ciprofloxacin and cefixime (B-F) with or without 10\% NHS for time indicated for each graph. Circles indicate mean+/-SD of independent repeats; $n=3$.

Comparisons between NHS alone and NHS plus C4BP-IgM, or antibiotic alone and $\mathrm{NHS}$ plus antibiotic at the respective time point were made by two-way ANOVA with Dunnett's multiple comparison test. In all graphs survival of bacteria was analyzed as $\mathrm{Log}(\mathrm{CFU} / \mathrm{mL})$ and horizontal dotted line refers to the starting number of bacteria used in the assay. ${ }^{*} p<0.05,{ }^{* \star} p<0.01,{ }^{* \star *} p<0.005,{ }^{* \star *} p<0.0001$.

Supplementary Figure 2 | Effect of LL-37 on bactericidal activity of serum against N. gonorrhoeae. FA1090 gonococci were incubated for 2 or 3 hours with $10 \%$ of $\mathrm{NHS}+/-\mathrm{OmCl}$ in the presence or in the absence of $0.8 \mu \mathrm{g} / \mathrm{mL}$ of LL-37 with $20 \mu \mathrm{g} / \mathrm{mL}$ of C4BP-IgM. Two-way ANOVA with Tukey's multiple-comparison test was performed to analyze differences among samples within the same hour. Bars indicate mean+/-SD, and circles refer to 3 independent repeats. Survival of bacteria was analyzed as $\mathrm{Log}(\mathrm{CFU} / \mathrm{mL})$ and horizontal dotted line indicates the starting number of bacteria used in the assay. ${ }^{*} \mathrm{p}<0.05,{ }^{* \star} \mathrm{p}<0.01,{ }^{\star \star \star} \mathrm{p}<0.005,{ }^{\star \star \star *} \mathrm{p}<$ 0.0001 .

Supplementary Figure 3 | FA1090 susceptibility to NHS or spectinomycin. (A) FA1090 gonococci were incubated for $30 \mathrm{~min}$ at $37^{\circ} \mathrm{C}$ with increasing concentrations of NHS, and survival was estimated as Log(CFU/mL) with horizontal dotted line indicates the starting number of bacteria used in the assay. Sample with $10 \% \mathrm{NHS}+\mathrm{C} 4 \mathrm{BP}-\operatorname{lgM}(10 \mu \mathrm{g} / \mathrm{mL})$ is used as a positive control for bactericidal activity of serum. (B) FA1090 gonococci were incubated for 3 hours with or without $10 \%$ NHS and increasing concentrations of spectinomycin. Internalization of sytox green was measured after 30 min incubation. In all graphs, bars indicate mean+/-SD, and circles show 3 independent repeats.

Supplementary Figure 4 | Azithromycin resistant strains of N. gonorrhoeae. (A) Flow cytometric determination of binding of fluorescently labeled C4BP and C4BP-IgM to FL29 and SA94 gonococci after 30 min of incubation at $37^{\circ} \mathrm{C}$. FA1090 and F62 were used as controls for positive and negative binding, respectively. (B, C) FL29 and SA94 gonococci were incubated for 1 or 2 hours with increasing concentrations of C4BP-IgM in the presence of $10 \% \mathrm{NHS}+/-\mathrm{OmCl}$. Circles display mean+/-SD of 3 independent experiments. At each time point, differences between 
samples with C4BP-IgM and those without the protein were compared using twoway ANOVA with Dunnett's multiple comparisons test. (D) FL29 gonococci were incubated for 1 or 2 hours with $10 \% \mathrm{NHS}+/-\mathrm{OmCl}$ or increasing concentrations of Cp40 or scrambled peptide (10, 50 or $100 \mu \mathrm{M})$ in the presence or in the absence of $2.5 \mu \mathrm{g} / \mathrm{mL}$ of C4BP-IgM. Scrambled peptide is used as irrelevant protein for Cp40-

\section{REFERENCES}

1. Quillin SJ, Seifert HS. Neisseria Gonorrhoeae Host Adaptation and Pathogenesis. Nat Rev Microbiol (2018) 16(4):226-40. doi: 10.1038/ nrmicro.2017.169

2. Rowley J, Vander Hoorn S, Korenromp E, Low N, Unemo M, Abu-Raddad LJ, et al. Chlamydia, Gonorrhoea, Trichomoniasis and Syphilis: Global Prevalence and Incidence Estimates, 2016. Bull World Health Organ (2019) 97(8):548-562P. doi: 10.2471/BLT.18.228486

3. Tan AK. Ophthalmia Neonatorum. N Engl J Med (2019) 380(2):e2. doi: 10.1056/NEJMicm1808613

4. Reekie J, Donovan B, Guy R, Hocking JS, Kaldor JM, Mak D, et al. Risk of Ectopic Pregnancy and Tubal Infertility Following Gonorrhea and Chlamydia Infections. Clin Infect Dis (2019) 69(9):1621-3. doi: 10.1093/cid/ciz145

5. Jennings LK, Krywko DM. Pelvic Inflammatory Disease. In: StatPearls. Treasure Island FL: StatPearls Publishing (2020). Available at: https://www. ncbi.nlm.nih.gov/pubmed/29763134.

6. Fleming DT, Wasserheit JN. From Epidemiological Synergy to Public Health Policy and Practice: The Contribution of Other Sexually Transmitted Diseases to Sexual Transmission of HIV Infection. Sex Transm Infect (1999) 75(1):317. doi: $10.1136 /$ sti.75.1.3

7. Unemo M, Seifert HS, Hook EW 3rd, Hawkes S, Ndowa F, Dillon JR. Gonorrhoea. Nat Rev Dis Primers (2019) 5(1):79. doi: 10.1038/s41572-0190128-6

8. Bignell C, Unemo MS.T.I.G.E.B. European. 2012 European Guideline on the Diagnosis and Treatment of Gonorrhoea in Adults. Int J STD AIDS (2013) 24 (2):85-92. doi: 10.1177/0956462412472837

9. WHO. WHO Guidelines for the Treatment of Neisseria Gonorrhoeae (2016). Available at: https://www.who.int/reproductivehealth/publications/rtis/ gonorrhoea-treatment-guidelines/en/.

10. Fifer H, Saunders J, Soni S, Sadiq ST, FitzGerald M. 2018 UK National Guideline for the Management of Infection With Neisseria Gonorrhoeae. Int $J$ STD AIDS (2020) 31(1):4-15. doi: 10.1177/0956462419886775

11. St Cyr S, Barbee L, Workowski KA, Bachmann LH, Pham C, Schlanger K, et al. Update to CDC's Treatment Guidelines for Gonococcal Infection, 2020. MMWR Morb Mortal Wkly Rep (2020) 69(50):1911-6. doi: 10.15585/ mmwr.mm6950a6

12. Unemo M, Ross J, Serwin A, Gomberg M, Cusini M, Jensen J. 2020 European Guideline for the Diagnosis and Treatment of Gonorrhoea in Adults. Int $J$ STD AIDS (2020), 956462420949126. doi: 10.1177/0956462420949126

13. Wi T, Lahra MM, Ndowa F, Bala M, Dillon JR, Ramon-Pardo P, et al. Antimicrobial Resistance in Neisseria Gonorrhoeae: Global Surveillance and a Call for International Collaborative Action. PloS Med (2017) 14(7):e1002344. doi: 10.1371/journal.pmed.1002344

14. Unemo M, Lahra MM, Cole M, Galarza P, Ndowa F, Martin I, et al. World Health Organization Global Gonococcal Antimicrobial Surveillance Program (WHO GASP): Review of New Data and Evidence to Inform International Collaborative Actions and Research Efforts. Sex Health (2019) 16(5):412-25. doi: 10.1071/SH19023

15. Centers for Disease Control and Prevention (U.S.) and National Center for Emerging Zoonotic and Infectious Diseases (U.S.). Division of Healthcare Quality Promotion. Antibiotic Resistance Coordination and Strategy Unit. Antibiotic resistance threats in the United States, 2019. (2019). doi: 10.15620/ cdc:82532

16. Tacconelli E, Carrara E, Savoldi A, Harbarth S, Mendelson M, Monnet DL, et al. Discovery, Research, and Development of New Antibiotics: The WHO Priority List of Antibiotic-Resistant Bacteria and Tuberculosis. Lancet Infect Dis (2018) 18(3):318-27. doi: 10.1016/S1473-3099(17)30753-3

17. Unemo M, Shafer WM. Antimicrobial Resistance in Neisseria Gonorrhoeae in the 21st Century: Past, Evolution, and Future. Clin Microbiol Rev (2014) 27 (3):587-613. doi: 10.1128/CMR.00010-14 treated samples. Two-way ANOVA with Dunnett's multiple comparisons tests was performed considering sample with NHS alone as reference. Bars display mean+/-SD with circles indicating independent repeats; $n=3$. Horizontal dotted line indicates the starting number of bacteria used in the assay. ${ }^{*} p<0.05,{ }^{* \star} p<0.01,{ }^{\star \star \star} p<0.005$, ${ }^{* \star \star \star} \mathrm{p}<0.0001$.

18. Hagman KE, Lucas CE, Balthazar JT, Snyder L, Nilles M, Judd RC, et al. The MtrD Protein of Neisseria Gonorrhoeae Is a Member of the Resistance/ Nodulation/Division Protein Family Constituting Part of an Efflux System. Microbiol (Read) (1997) 143:2117-25. doi: 10.1099/00221287-143-7-2117

19. Lan PT, Golparian D, Ringlander J, Van Hung L, Van Thuong N, Unemo M. Genomic Analysis and Antimicrobial Resistance of Neisseria Gonorrhoeae Isolates From Vietnam in 2011 and 2015-16. J Antimicrob Chemother (2020) 75(6):1432-8. doi: 10.1093/jac/dkaa040

20. Ma KC, Mortimer TD, Grad YH. Efflux Pump Antibiotic Binding Site Mutations Are Associated With Azithromycin Nonsusceptibility in Clinical Neisseria Gonorrhoeae Isolates. mBio (2020) 11(4):e01509-20. doi: 10.1128/ mBio.01509-20

21. Golparian D, Bazzo ML, Golfetto L, Gaspar PC, Schörner MA, Schwartz Benzaken A, et al. Genomic Epidemiology of Neisseria Gonorrhoeae Elucidating the Gonococcal Antimicrobial Resistance and Lineages/ Sublineages Across Brazil, 2015-16. J Antimicrob Chemother (2020) 75 (11):3163-72. doi: 10.1093/jac/dkaa318

22. Bettoni S, Shaughnessy J, Maziarz K, Ermert D, Gulati S, Zheng B, et al. C4BPIgM Protein as a Therapeutic Approach to Treat Neisseria Gonorrhoeae Infections. JCI Insight (2019) 4(23):e131886. doi: 10.1172/jci.insight.131886

23. Dutcher BS, Reynard AM, Beck ME, Cunningham RK. Potentiation of Antibiotic Bactericidal Activity by Normal Human Serum. Antimicrob Agents Chemother (1978) 13(5):820-6. doi: 10.1128/AAC.13.5.820

24. Watanabe K, Kin R, Murakami M, Kondo M. Influence of Human Serum on Bactericidal Activity of Ceftizoxime Sodium. Chemotherapy (1986) 32(2):1137. doi: $10.1159 / 000238399$

25. Darveau RP, Cunningham MD. Influence of Subinhibitory Concentrations of Cephalosporins on the Serum Sensitivity of Pseudomonas Aeruginosa. J Infect Dis (1990) 162(4):914-21. doi: 10.1093/infdis/162.4.914

26. Franiczek R, Jankowski S. Synergistic Effect of Cefotaxime and Normal Human Serum on Bactericidal Activity Against Urinary Strains of Escherichia Coli With Capsular Antigen K1. Acta Microbiol Pol (1993) 42 (3-4):243-50.

27. Citterio L, Franzyk H, Palarasah Y, Andersen TE, Mateiu RV, Gram L. Improved In Vitro Evaluation of Novel Antimicrobials: Potential Synergy Between Human Plasma and Antibacterial Peptidomimetics, AMPs and Antibiotics Against Human Pathogenic Bacteria. Res Microbiol (2016) 167(2):72-82. doi: 10.1016/ j.resmic.2015.10.002

28. Pruul H, Reynolds BL. Interaction of Complement and Polymyxin With Gram-Negative Bacteria. Infect Immun (1972) 6(5):709-17. doi: 10.1128/ iai.6.5.709-717.1972

29. Vaara M, Vaara T. Sensitization of Gram-Negative Bacteria to Antibiotics and Complement by a Nontoxic Oligopeptide. Nature (1983) 303(5917):526-8. doi: $10.1038 / 303526 \mathrm{a} 0$

30. Dalhoff A. In Vitro and In Vivo Effect of Immunoglobulin G on the Integrity of Bacterial Membranes. Infection (1984) 12(3):214-22. doi: 10.1007/BF01640908

31. Pruul H, McDonald PJ. Potentiation of Antibacterial Activity of Azithromycin and Other Macrolides by Normal Human Serum. Antimicrob Agents Chemother (1992) 36(1):10-6. doi: 10.1128/AAC.36.1.10

32. Heesterbeek DAC, Martin NI, Velthuizen A, Duijst M, Ruyken M, Wubbolts $\mathrm{R}$, et al. Complement-Dependent Outer Membrane Perturbation Sensitizes Gram-Negative Bacteria to Gram-Positive Specific Antibiotics. Sci Rep (2019) 9(1):3074. doi: 10.1038/s41598-019-38577-9

33. Hitchcock PJ, Hayes SF, Mayer LW, Shafer WM, Tessier SL. Analyses of Gonococcal H8 Antigen. Surface Location, Inter- and Intrastrain Electrophoretic Heterogeneity, and Unusual Two-Dimensional Electrophoretic Characteristics. J Exp Med (1985) 162(6):2017-34. doi: 10.1084/jem.162.6.2017

34. McQuillen DP, Gulati S, Rice PA. Complement-Mediated Bacterial Killing Assays. Methods Enzymol (1994) 236:137-47. doi: 10.1016/0076-6879(94) 36013-8 
35. Gulati S, Rice PA, Ram S. Complement-Dependent Serum Bactericidal Assays for Neisseria Gonorrhoeae. Methods Mol Biol (2019) 1997:267-80. doi: 10.1007/978-1-4939-9496-0_16

36. Blom AM, Volokhina EB, Fransson V, Strömberg P, Berghard L, Viktorelius $\mathrm{M}$, et al. A Novel Method for Direct Measurement of Complement Convertases Activity in Human Serum. Clin Exp Immunol (2014) 178 (1):142-53. doi: $10.1111 /$ cei.12388

37. Stone MRL, Masi M, Phetsang W, Pagès JM, Cooper MA, Blaskovich MAT. Fluoroquinolone-Derived Fluorescent Probes for Studies of Bacterial Penetration and Efflux. Medchemcomm (2019) 10(6):901-6. doi: 10.1039/C9MD00124G

38. Stone MRL, Łapińska U, Pagliara S, Masi M, Blanchfield JT, Cooper MA, et al. ORCID Logo, Fluorescent Macrolide Probes - Synthesis and Use in Evaluation of Bacterial Resistance. RSC Chem Biol (2020) 1(5):395-404. doi: 10.1039/ D0СB00118J

39. Mastellos DC, Yancopoulou D, Kokkinos P, Huber-Lang M, Hajishengallis G, Biglarnia AR, et al. Compstatin: A C3-Targeted Complement Inhibitor Reaching its Prime for Bedside Intervention. Eur J Clin Invest (2015) 45 (4):423-40. doi: 10.1111/eci.12419

40. Ram S, Cullinane M, Blom AM, Gulati S, McQuillen DP, Monks BG, et al. Binding of C4b-Binding Protein to Porin: A Molecular Mechanism of Serum Resistance of Neisseria Gonorrhoeae. J Exp Med (2001) 193(3):281-95. doi: 10.1084/jem.193.3.281

41. Xhindoli D, Pacor S, Benincasa M, Scocchi M, Gennaro R, Tossi A. The Human Cathelicidin LL-37-A Pore-Forming Antibacterial Peptide and HostCell Modulator. Biochim Biophys Acta (2016) 1858(3):546-66. doi: 10.1016/ j.bbamem.2015.11.003

42. Nordahl EA, Rydengård V, Nyberg P, Nitsche DP, Mörgelin M, Malmsten M, et al. Activation of the Complement System Generates Antibacterial Peptides. Proc Natl Acad Sci USA (2004) 101(48):16879-84. doi: 10.1073/ pnas. 0406678101

43. Greenberg L, Diena BB, Ashton FA, Wallace R, Kenny CP, Znamirowski R, et al. Gonococcal Vaccine Studies in Inuvik. Can J Public Health (1974) 65(1):29-33.

44. Boslego JW, Tramont EC, Chung RC, McChesney DG, Ciak J, Sadoff JC, et al. Efficacy Trial of a Parenteral Gonococcal Pilus Vaccine in Men. Vaccine (1991) 9(3):154-62. doi: 10.1016/0264-410X(91)90147-X

45. Bolla JM, Alibert-Franco S, Handzlik J, Chevalier J, Mahamoud A, Boyer G, et al. Strategies for Bypassing the Membrane Barrier in Multidrug Resistant Gram-Negative Bacteria. FEBS Lett (2011) 585(11):1682-90. doi: 10.1016/ j.febslet.2011.04.054

46. Stokes JM, MacNair CR, Ilyas B, French S, Côté JP, Bouwman C, et al. Pentamidine Sensitizes Gram-Negative Pathogens to Antibiotics and Overcomes Acquired Colistin Resistance. Nat Microbiol (2017) 2:17028. doi: 10.1038/nmicrobiol.2017.28

47. Alamiri F, Riesbeck K, Hakansson AP. HAMLET, a Protein Complex From Human Milk has Bactericidal Activity and Enhances the Activity of Antibiotics Against Pathogenic Streptococci. Antimicrob Agents Chemother (2019) 63(12):e01193-19. doi: 10.1128/AAC.01193-19
48. Mahmood HY, Jamshidi S, Sutton JM, Rahman KM. Current Advances in Developing Inhibitors of Bacterial Multidrug Efflux Pumps. Curr Med Chem (2016) 23(10):1062-81. doi: 10.2174/0929867323666160304150522

49. Shaughnessy J, Lewis LA, Zheng B, Carr C, Bass I, Gulati S, et al. Human Factor H Domains 6 and 7 Fused to IgG1 Fc Are Immunotherapeutic Against Neisseria Gonorrhoeae. J Immunol (2018) 201(9):2700-9. doi: 10.4049/ jimmunol.1701666

50. Shaughnessy J, Tran Y, Zheng B, DeOliveira RB, Gulati S, Song WC, et al. Development of Complement Factor H-Based Immunotherapeutic Molecules in Tobacco Plants Against Multidrug-Resistant Neisseria Gonorrhoeae. Front Immunol (2020) 11:583305. doi: 10.3389/fimmu.2020.583305

51. Berends ET, Mohan S, Miellet WR, Ruyken M, Rooijakkers SH. Contribution of the Complement Membrane Attack Complex to the Bactericidal Activity of Human Serum. Mol Immunol (2015) 65(2):328-35. doi: 10.1016/ j.molimm.2015.01.020

52. Xie CB, Jane-Wit D, Pober JS. Complement Membrane Attack Complex: New Roles, Mechanisms of Action, and Therapeutic Targets. Am J Pathol (2020) 190(6):1138-50. doi: 10.1016/j.ajpath.2020.02.006

53. Rouquette C, Harmon JB, Shafer WM. Induction of the mtrCDE-Encoded Efflux Pump System of Neisseria Gonorrhoeae Requires MtrA, an AraC-Like Protein. Mol Microbiol (1999) 33(3):651-8. doi: 10.1046/j.1365-2958.1999.01517.x

54. Jerse AE, Sharma ND, Simms AN, Crow ET, Snyder LA, Shafer WM. A Gonococcal Efflux Pump System Enhances Bacterial Survival in a Female Mouse Model of Genital Tract Infection. Infect Immun (2003) 71(10):557682. doi: 10.1128/IAI.71.10.5576-5582.2003

55. Ma KC, Mortimer TD, Hicks AL, Wheeler NE, Sánchez-Busó L, Golparian D, et al. Adaptation to the Cervical Environment Is Associated With Increased Antibiotic Susceptibility in Neisseria Gonorrhoeae. Nat Commun (2020) 11 (1):4126. doi: 10.1038/s41467-020-17980-1

Conflict of Interest: The authors declare that the research was conducted in the absence of any commercial or financial relationships that could be construed as a potential conflict of interest.

Publisher's Note: All claims expressed in this article are solely those of the authors and do not necessarily represent those of their affiliated organizations, or those of the publisher, the editors and the reviewers. Any product that may be evaluated in this article, or claim that may be made by its manufacturer, is not guaranteed or endorsed by the publisher.

Copyright $\odot 2021$ Bettoni, Maziarz, Stone, Blaskovich, Potempa, Bazzo, Unemo, Ram and Blom. This is an open-access article distributed under the terms of the Creative Commons Attribution License (CC BY). The use, distribution or reproduction in other forums is permitted, provided the original author(s) and the copyright owner(s) are credited and that the original publication in this journal is cited, in accordance with accepted academic practice. No use, distribution or reproduction is permitted which does not comply with these terms. 